\title{
Towards a more inclusive future
}

\section{On the delicate balance between economic change and social stability in a time of globalisation}

\author{
Kees van Paridon (iD
}

Published online: 7 September 2018

(C) The Author(s) 2018

\begin{abstract}
Globalization and technological developments are very positive developments, but increasingly their negative consequences become more severe, especially for lower educated groups in society. Also the major changes in educational levels of employed people have a similar impact. This article shows a number of long term developments for the Netherlands, showing that until the 1980s the many changes could be handled more or less adequately to keep the society inclusive, but that thereafter the social divisions have increased considerably. The recent rise in social discontent, in populism, can be connected to this rising inequality. This pattern is not typical Dutch, it seems relevant for most develoed economies.
\end{abstract}

Keywords Globalisation · Educational distribution · Income distribution · Populism · Netherlands

\section{On inclusive dynamism}

In many Western countries, also in the Netherlands and Germany, social discontent has increased considerably in the last decades. Discontent about job losses, about immigrants, about Europe, about globalisation, about the elite and so on has been listed among the causes. People feel excluded and believe they have lost out. After the British unexpectedly voted for Brexit last year, and Trump was equally unexpectedly elected as President of the United States, numerous elections that were coming up - in Austria, France, the Netherlands and Germany-were anticipated with some dread. These elections have not produced the feared seismic shifts, but that does not mean that everything is back under control again. It cannot be excluded, however,

K. van Paridon $(\bowtie)$

Erasmus University Rotterdam, Rotterdam, The Netherlands

E-Mail: vanparidon@essb.eur.nl 
that the situation will escalate further, for example if the inevitable cyclical downturn occurs in the next few years, or if social inequalities increase even further.

The focus in this article is on globalisation and technological development, two phenomena that have become more and more intertwined in recent decades. The assumption is that people's uncertainty today about jobs, incomes and pensions and their children's future is greater than it has been for a long time. That uncertainty and discontent are closely related to globalisation and technological development, but also to other factors as increased education and demographics.

The Dutch Council for Economic Affairs wrote the following on this subject in 2007: 'The current public debate is dominated by unrest (...) because, according to the received wisdom, globalisation is accompanied by shifts in the distribution of labour and income on a global scale. Jobs are being lost here to far-away countries, and wages here are coming under pressure due to the influx of cheap labour from elsewhere. The perception, therefore, is that globalisation is not so much accompanied by an increase in prosperity, but above all by negative effects on the distribution of labour and income. This feeds the fear of the strange and the uncertain. People sense that it is not only the inequality between poor and rich countries that is increasing, but that the same is true of the inequality within countries.' 1.

This observation of the fear of globalisation can be found already much earlier. Thomas Macaulay, for example, remarked that 'Free trade, one of the greatest blessings which a government can confer on a people, is in almost every country unpopular'. That quotation from Macaulay dates from 1824. According to Macaulay, politicians and citizens are always tempted to pursue their own interests, often under the guise of patriotism or the national interest. This attitude is detrimental to the general interest, and hence also to the interest of many individuals in the longer term. He feared that in a democracy this seductive siren's song would lead many people to vote against their own interests. To vote for protectionism and against free trade, for instance. Similar passages can be found on the subject of technological development. Think of Ned Ludd's fight against the machine looms in England in 1779. As he saw it, many jobs would be lost because of these machines, and this would in turn lead to widespread poverty. In short, we are talking about developments that have preoccupied us for a long time.

This article deals with this tension, between what is good for society as a whole, but can be at the same time disadvantageous for some individuals, sectors or regions. Why are economists and politicians often so outspoken in favour of globalisation and technological development? Why do some people nonetheless get a raw deal? How has this problem been tackled in the past, and what can we do about it now? An inevitably rough outline will be given of the extent to which, both nationally and internationally, the precarious balance between economic change and social stability has come under pressure. I will start with Milanovic's famous 'elephant', and then briefly show - on the basis of a number of developments-how that balance has come under pressure in the Netherlands. After this, I will trace the possible link

\footnotetext{
1 See Raad voor Economisch Advies (Dutch Council for Economic Affairs) (2007), Van de verdeling komt de welvaart (Distribution is determining welfare), REA-advies, September 2007.
} 
between these developments and the emerging populism. I will finish with a number of recommendations on how to reduce this imbalance.

\section{A magic graph}

Seen from a global perspective, economic development in recent decades, at least until 2008, can be described as remarkably positive. Thanks to globalisation and technological development, together with an economic policy based on free trade and liberalisation, the increased prosperity at the global level during this period is nothing short of impressive. Branko Milanovic's global inequality graph makes this clear $^{2}$.

Fig. 1 covers the entire world population. Each individual's income is calculated, and the income increase in the period 1988-20083. All these global citizens are ranked from lowest to highest on the basis of their income level in 1988. On the left, we find the poorer inhabitants of the globe in 1988, and on the right the richer ones. Those on the left mainly consist of people from countries in Africa, Asia and Latin America, while those on the right are mainly people from the developed countries. Due to the differences in income increase and ongoing demographic change ${ }^{4}$, this percentile distribution will look different in 2008 from the way it looked in 1988. There is nothing surprising about any of this.

Milanovic then looked at how the income of all these people had developed over the period 1988-2008. Almost across the board there is a marked improvement, especially for the lower incomes. For the group between the 10th and 70th percentile,

Fig. 1 Change in real income (at PPP), 1988-2008. Source: Milanovic (2016)

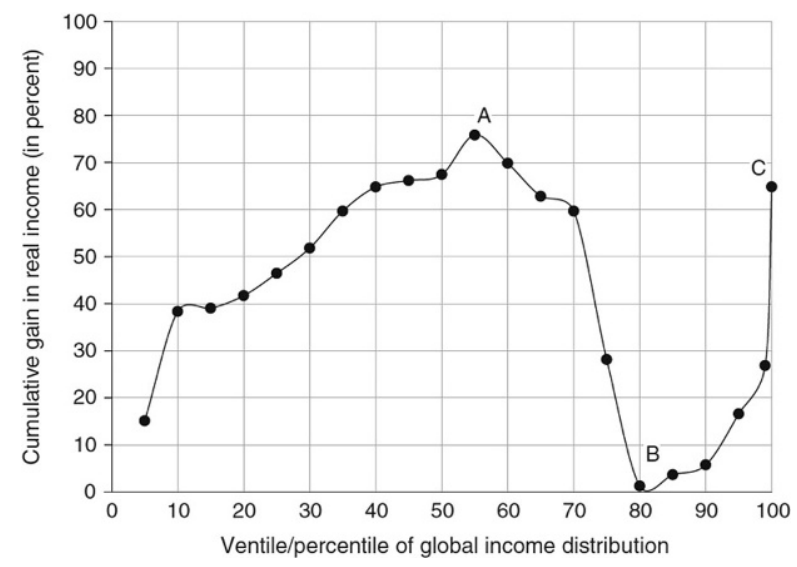

2 See Milanovic (2016), Global inequality. A new approach for the age of globalization, Boston: Harvard University Press.

3 Of course, the use of GDP per capita as a yardstick is open to debate. Many considerations are not taken properly into account. At the same time, though, this indicator is still relevant as a proxy. Look at the close connection with, for example, the Human Development Index, as developed by Amartya Sen and Mahbub ul Haq. See United Nations Development Programme (2016), Human Development Report 2016. Human Development for Everyone, New York.

4 E.g. strong population growth in Africa, compared with minimal growth in Western Europe. 
in other words roughly $60 \%$ of the world's population, there was a real income improvement in 20 years of $60 \%$ or even slightly more. Partly as a result, the number of people below the absolute poverty level, with an income of less than 1.90 dollars per day, fell from $35 \%$ to $10 \%$ in the period 1985-2014, according to figures from the World Bank. ${ }^{5}$ This is a truly impressive progress.

Two groups deviate from this pattern. Firstly, it is clear from this graph that among the very poorest, hardly any improvement in income took place in these 20 years. Strong population growth, natural disasters, incompetent governance, corruption and religious or political struggles will certainly have played a role in this. There is clearly much still to be done here ${ }^{6}$.

The second group on this graph, from percentile 80 onwards, does show a much lower income growth than the overall positive trend. In global terms, of course, these people had a relatively good income position in 1988. Their real income growth in the period under consideration was limited to roughly 10 to $20 \%$. Only among the very richest people in these countries was the income increase comparable with that of the large central group ${ }^{7}$. For the people around the 80th percentile, real income in the period under consideration actually fell slightly. These are people from the richer countries ${ }^{8}$, who are there at the bottom of the income scale; in that context they are therefore often described as poor. The people around the 80th decile clearly did not benefit from the relatively favourable economic development. Even at the 90th percentile, the increase was relatively limited.

There surely has been favourable progress in global terms-and this cannot be emphasised often enough-, but for some groups there has been a relative decline. Evidently they have not been able to benefit from this increase to the same extent as many others. That is not pleasant, in the same way that any relative decline rankles. This decline is also revealed in other ways: job losses, uncertainty about finding a job, uncertainty about pensions or benefits, uncertainty about the future of their children. This uncertainty is the central theme here.

\section{Long-term changes}

There are many factors that impart dynamism to the economy and to society, that have together contributed to this growing uncertainty in recent decades. Here the post-war development of growth and productivity, income distribution, demographics, educational levels, and internationalisation are considered. These developments create opportunities and chances for many, but threats and uncertainties for others. They are very relevant to economic development, but at the same time they also affect social stability. The data presented here relate mainly to the Netherlands, but

\footnotetext{
5 See http://data.worldbank.org/indicator/SI.POV.DDAY?view=chart.

6 The World Bank is working for a world without poverty, and hopes to have reached this situation by 2030. See https://blogs.worldbank.org/developmenttalk/measuring-poverty-rapidly-changing-world.

7 Within this category, there is then a tiny group with much higher income increases. But that group is very limited in extent.

8 The inhabitants of former communist countries experienced a clear income recovery after 2000.
} 
the same observations can be made in many Western countries. And that means that this uncertainty is not a specifically Dutch phenomenon, but detectable in many other countries too.

\subsection{Economic growth and productivity growth}

Imperfect though it may be, at present there is no better indicator to measure the growth of prosperity, real income growth, than Gross National Product (GNP). Fig. 2 shows that the highest growth mainly occurred in the 1950s and 1960s. Thereafter growth was not that high anymore. There were brief upsurges, especially in the late 1990s, but that remarkably long-lasting and strong growth of the '50s and '60s was not equalled. In addition, economic growth in the Netherlands was significantly lower around 1982 and then again around 2009'. In short, average growth of GNP in the Netherlands ${ }^{10}$ rose sharply in the years up to 1970 . After that, there were upsurges, but the average was lower.

A country's economic growth depends on its amount and quality of capital and labour and on its productivity growth. With more and better buildings and machines, more numerous and highly skilled people and more knowledge, GNP will increase. Fig. 3 is about these different contributions, but this time for the Eurozone. These

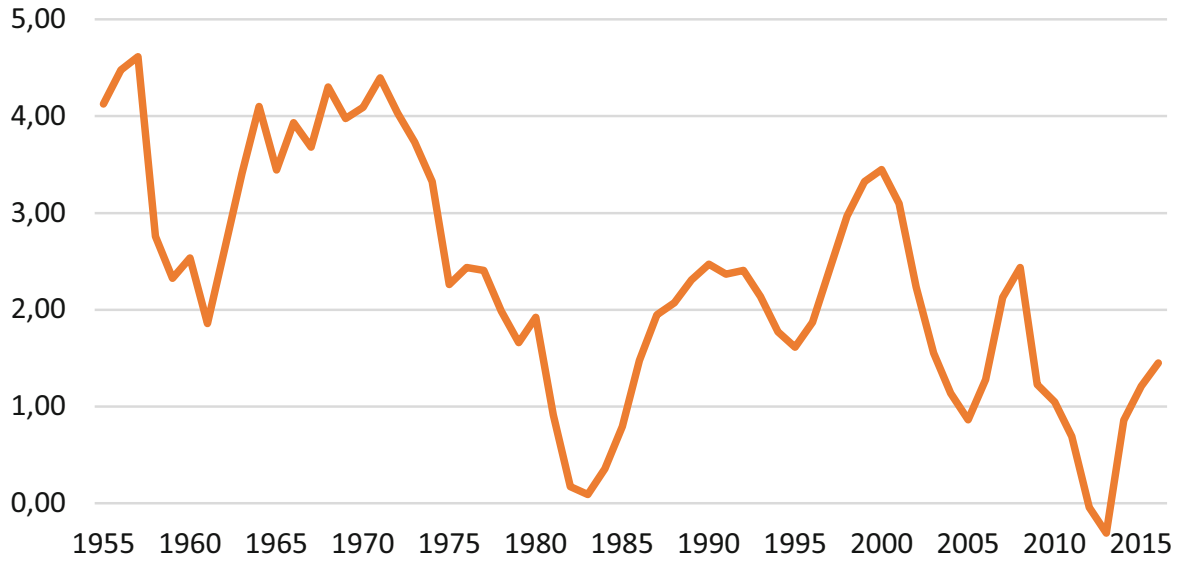
$-1,00$

Fig. 2 Growth in real GNP per capita, 5-year average, 1950-2016. Source: Maddison (See http://www. ggdc.net/maddison/maddison-project/home.htm) and Statistics Netherlands (Statistics Netherlands, Statline)

\footnotetext{
9 The question may be asked how serious this lower growth is. It is clear from the knock-on effects of lower growth on the job market (in a recession and crisis, many jobs are lost), unemployment (which rises sharply) and government finances (budget deficits increase, which means that debt does too) that structurally lower growth cannot be achieved smoothly overnight.

${ }^{10}$ Similar observations can be made for all Western European countries.

${ }^{11}$ See Bergeaud et al. (2017), Total factor productivity in advanced countries: a long-term perspective, in: OECD, International Productivity Monitor, 32, pp. 6-24.
} 


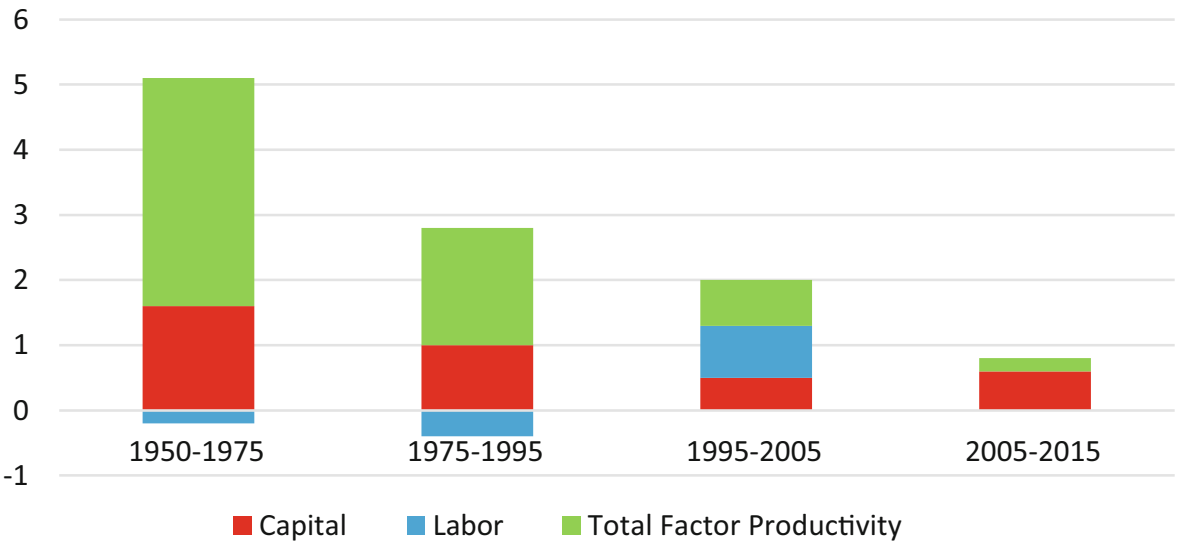

Fig. 3 Economic growth per production factor in the Eurozone, 1950-2015. Source: Bergeaud et al. (2017)

data come from recent research by Bergeaux, Cette and Lecat ${ }^{11}$. They analyse the development of total factor productivity ${ }^{12}$ in the developed countries over the long term.

The trend is clear for the Eurozone. Here too, economic growth was relatively strong until the 1970s, but the growth of both GNP and factor productivity decreased sharply after 1975. The fall in productivity growth is particularly striking. The general public impression is that the pace of technological development is becoming faster and faster, with IT, the Internet and all the other breakthroughs we have seen over the last 30 years. Yet these breakthroughs are not reflected in the development of productivity. Robert Solow's statement from 1987 still appears to be true ${ }^{13}$ : 'You can see the computer age everywhere but in the productivity statistics'. This paradox has seemed to hold just as good since then, too. Recently, ABN AMRO's economics office issued a paper on productivity growth ${ }^{14}$. It too shows that growth in labour productivity has been declining in recent decades (data from 1992 onwards). It is also observed that capital intensity is growing at a slower rate in the Eurozone, and has in fact fallen slightly in recent years ${ }^{15}$. With decreasing capital and labour inputs, lower labour productivity growth is almost inevitable.

For the Netherlands, the same conclusion can be drawn regarding the development of labour productivity as for the Eurozone. Based on data from the Penn World Table, the development of labour productivity can be traced from 1950 onwards ${ }^{16}$. The results, as shown in Fig. 4, are in line with those of Bergeaud et al. Growth in labour productivity was initially strong, but declined sharply after 1970 .

\footnotetext{
12 Economic growth is due to a large number of causes, such as labour, capital and other factors such as entrepreneurship and technology. These latter factors are referred to as factor productivity.

13 In The New York Times Book Review, 12-7-1987, p. 36.

14 See ABN AMRO Economic Department (2017), Why is productivity growth so low?, Amsterdam.

15 It is still increasing slightly in the Netherlands.

16 Penn World Tables version 9.0, via http://www.rug.nl/ggdc/productivity/pwt/.
} 


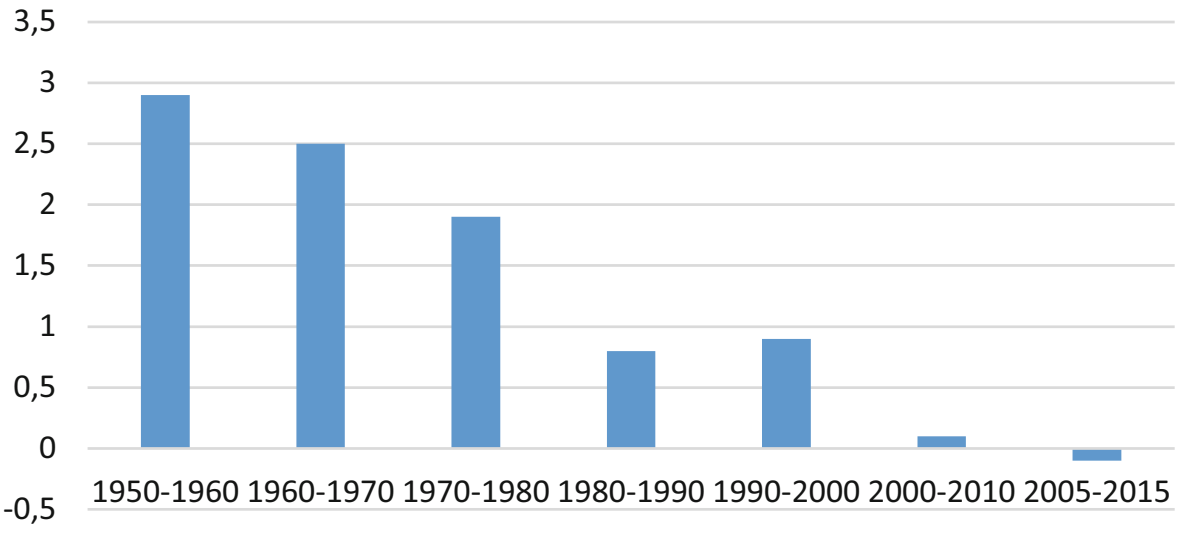

Fig. 4 Annual labour productivity growth, 1950-2015. Source: Penn World Tables

Convincing though these data are, there is still a slight element of doubt. With the introduction of PCs, the Internet, mobile phones, transport technology and new materials, mentioned earlier, with all the associated changes in production processes and organisational structures, with the increasingly skilled labour force, far-reaching, productivity-enhancing changes have been implemented in so many places that it can be expected that productivity growth will accelerate again one day. Maybe it is a measurement problem. The ever faster succession of new products, with ever better performance, creates problems for statistical agencies in performing appropriate price, quality and productivity measurement. In addition, these changes are increasingly taking place in the service area, where the recording of output, productivity and added value is more difficult than in industry or agriculture, with its much more physical production yield.

The overall picture is that in both the Netherlands and the Eurozone, there was relatively strong economic growth, including labour productivity growth, until the 1980s, but that growth has decreased significantly in the last 40 years. This is particularly striking for labour productivity. Despite all technological developments and despite the increased focus on market forces since the 1980s, productivity growth has not risen again; in fact, it seems to have declined further. This is not just striking - it is also problematic. In the past, the 'national pie' grew rapidly, which also made the distribution issue easier. Now that the pie is scarcely increasing in size any longer, growth for one is much more likely to mean a decrease for someone else. This will become even more pressing in the future. As will be discussed below, we can expect to face a shrinking labour force and a rising number of older people in the years ahead, and hence growing demand for pension and health care benefits. It will be necessary to finance these extra expenses, and to facilitate real income improvements for the working population at the same time; an increase in productivity could alleviate this problem. For the time being, however, there is no prospect of that. 


\subsection{Income distribution}

Chap. 2 started with Milanovic's graph. At a global level, widespread income growth was observable, with the planet's poorer inhabitants doing relatively well. This suggests decreasing global income inequality, yet at the same time, within countries there was in fact often growing inequality. In these countries, the richer showed strong income (and wealth) growth, while the poorer lagged behind in income growth. How has income distribution developed in the Netherlands? What follows is a brief outline of personal income distribution and macro income distribution.

\subsubsection{Personal income distribution}

Data series for Dutch income distribution have not been published for the entire post-war period. However, there are data for the period up to the mid-70s, and data from 1977 onwards. In 1977, Pen and Tinbergen published a book entitled Naar een rechtvaardiger inkomensverdeling ('Towards a fairer income distribution') ${ }^{17}$. In Sect. 1.10, they presented 24 sources which gave a picture of income development since 1938. Their conclusion was that almost all data pointed to a gradual levelling out $^{18}$. Their expectation was that inequality would carry on decreasing. One of the sources they used in their book was a preliminary study of the Netherlands Scientific Council for Government Policy (WRR) by Mustert from $1976^{19}$. In one of the tables in that preliminary study, a time series with the Gini coefficient was given.

Fig. 5 shows the development of the Gini coefficient ${ }^{20}$, based on the income classification from the year in question. These data support the view of Pen and Tinbergen that there had been a steady development towards greater equality, although the progress from 1955 onwards has been relatively limited.

If we then look at the development after $1977^{21}$, Fig. 6 based on OECD data ${ }^{22}$ shows first an increase in inequality, and then a return to the level of 1977. The last two years show an increase again, but it has to be noted that a new income definition was being used at this point. These data do not show a clear trend over the entire period. There is no further decrease in income inequality, but it is also impossible to say whether there is a (slight) increase. A very recent publication by two researchers at Statistics Netherlands ${ }^{23}$ shows that the increase in the Gini

\footnotetext{
17 See Pen and Tinbergen (1977), Naar een rechtvaardiger inkomensverdeling (Towards a more just income distribution), Amsterdam: Elsevier.

18 See Pen and Tinbergen, p. 49.

19 See Mustert (1976), Van dubbeltjes en kwartjes (Of poor and rich people), Report, The Hague. The average of 1964 and 1966 was taken for the result for 1965.

20 A Gini coefficient value of 0 means that there is complete equality, while a value of 1 means that there is complete inequality.

21 The data in Fig. 6 are not directly comparable to those in Fig. 5.

22 See OECD Income Distribution Database (IDD). See http://www.oecd.org/social/income-distributiondatabase.htm, retrieved on 15-8-2017.

23 See van den Brakel and Otten (2017), Door crisis en vergrijzing stijgt ongelijkheid in primair inkomen (Through crisis and greying Dutch primary income inequality increases), Economisch Statistische Berichten, ESB, 102(4756), 579-582.
} 


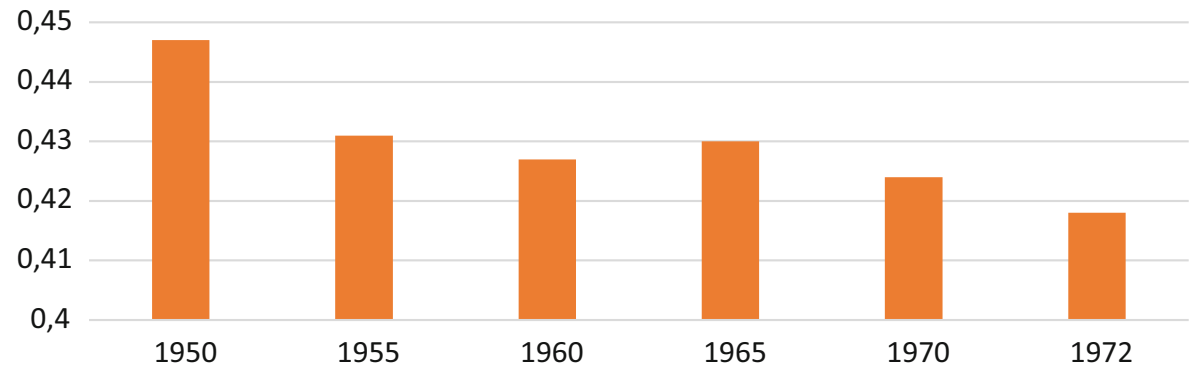

Fig. 5 Income inequality for primary income based on Gini coefficient for the Netherlands, 1950-1972. Source: Mustert (1976)

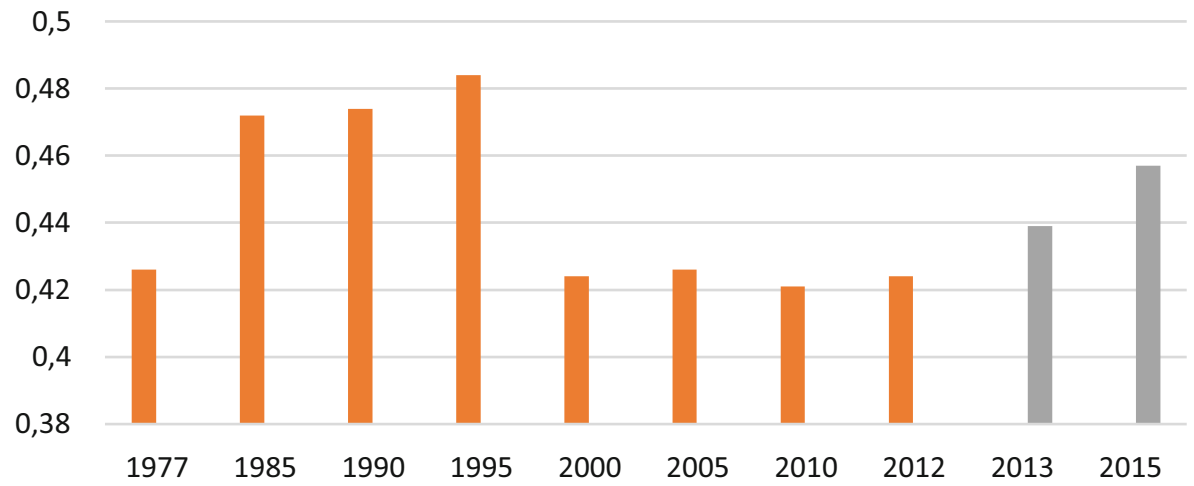

Fig. 6 Income inequality for primary income based on Gini coefficient for the Netherlands, 1977-2015. Source: OECD, see note 22

coefficient for primary income in recent years (see Fig. 8) is related to the effects of the 2008 crisis and population ageing. On the other hand, the sharp increase in the participation of women has had a levelling effect. In terms of the Gini coefficient for disposable income, there has been a fairly constant development, although here too, the index has shown a slight upturn in recent years.

This admittedly limited selection of data on income distribution shows that there was a moderate decrease in inequality in the period up to 1975 , while in the period after 1977, there was a stable situation or a slight increase. From an international perspective, the Netherlands occupied a middle position. In the Scandinavian countries and in some continental countries such as Austria, inequality was lower, while in the English-speaking countries and many countries in Southern Europe, inequality was greater.

\subsubsection{Macro-economic income distribution}

What do we know about the development of macro-economic income distribution? In the 1970s and 1980s, the development of the labour income share (LIS), that part of added value or GNP that is allocated to the labour factor (wages or pay), 


\section{4,0}

82,0

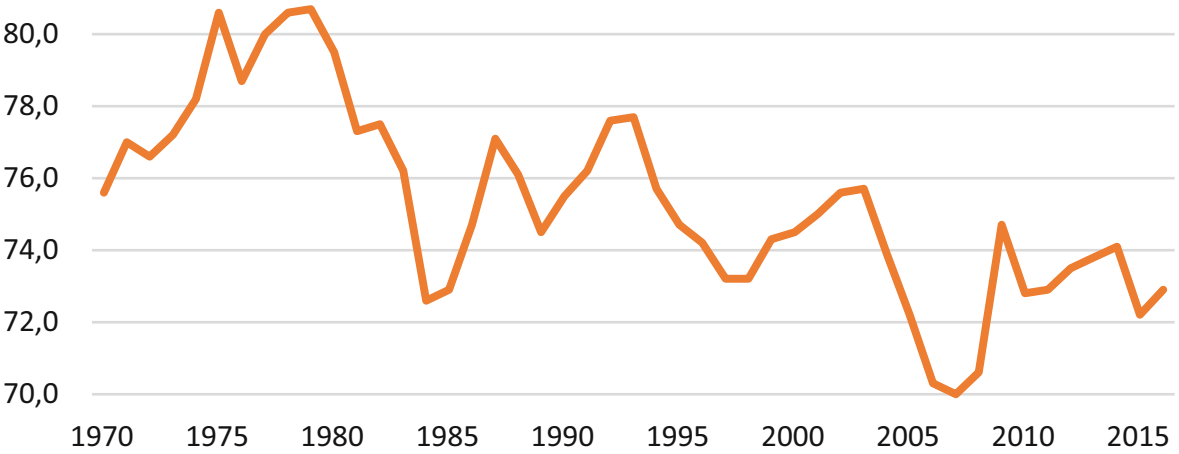

Fig. 7 Labour income share, 1970-2016, according to new definition. Source: CPB, see note 24

was an important issue in debate about economic policy and pay trends. Because the LIS had risen sharply then, to about $90 \%$, there was hardly anything left for the capital factor. This was a major cause for insufficient investing of companies, with stagnating growth and rising unemployment as a consequence.

The value of LIS is sensitive to definition adjustments. Recently such adjustment has been made in the Netherlands. Fig. 7 shows the development of the LIS for the period 1970-2016, based on the latest definition ${ }^{24}$. The CPB, Statistics Netherlands and DNB (the Dutch Central Bank) recently issued a paper on this subject ${ }^{25}$. In their opinion, better account needs to be taken of the increasing share of the selfemployed and the differences in income development between employees and the self-employed.

The development of the labour income share has shown a fairly consistent decline since the early $1980 \mathrm{~s}^{26}$, with some stabilisation since the mid-2000s ${ }^{27}$. This decline in the LIS can be related to the restrained wage growth in the Netherlands since

\footnotetext{
24 Data derive from Appendix 2 of CPB Netherlands Bureau for Economic Policy Analysis (2017), Macro Economische Verkenning 2017 (Macro Economic Forecast 2017), The Hague, Appendix 1.

25 See CPB, Statistics Netherlands and DNB (2017), Herziening methode arbeidsinkomensquote (Revision method labour income share), The Hague. The data were retrieved from Statline.

26 This development was also seen in many other countries after 1980. See Piketty (2014), Capital in the 21 Century, Cambridge: Harvard University Press, as well as OECD (2012), Labour losing to capital: What explains the declining labor share?, In Organisation for Economic Cooperation and Development, Employment Outlook 2012, Chap. 3, pp. 109-161, and International Monetary Fund (2017a), Understanding the downward trend in labor income shares, in IMF, World Economic Outlook 2017, Chap. 3, April 217, Washington.

27 This picture is consistent with that of Van Bavel. In an article in the ESB, Van Bavel outlines the longterm development of the labour share. He refers to a steady increase from 1870 onwards until the early 1980 s, after which a decline sets in. The level today is comparable with that of the 1950s. These shifts are related to large-scale social processes, and government policy has little influence on them. See van Bavel (2016), De stijging en daling van het arbeidsaandeel over de lange termijn (The rise and decline of the labor income share in the long run), Economisch Statistische Berichten, 101(4743), 696-701.
} 
the early 1980s. High unemployment in the 1980s, the mass entry of women into the labour market in the 1990s and increased immigration in the most recent period have all helped to ensure an ample labour market, especially at the lower end, making wage increases less self-evident. Partly as a result of this, labour costs have shown relatively little increase, which has strengthened the competitive position of the Netherlands. Dutch exports have risen sharply, resulting in a strong balance of payments surplus. There has been criticism of this excessively positive balance, especially from abroad ${ }^{28}$. There have therefore been calls for stronger wage growth ${ }^{29}$. Germany is in a similar situation.

In conclusion, there appear to be relatively limited differences in income distribution between the period up to 1980 and that after 1980. In the first period, income inequality decreases slightly. In the years after 1980, income distribution remains fairly constant, with a slight increase in recent years, while the LIS in the same period shows a slight downward trend. This means that at a time when incomes have scarcely risen, the distribution has shifted slightly to the detriment of income from pay and benefits ${ }^{30}$.

\subsection{Demographic changes}

There have been major demographic changes in the last 50 years. In the first place, the population increase has gradually tailed off: the Netherlands is approaching the point at which the total population will cease to grow. In 1960, there were just 10 million people living in the Netherlands, by 2000 there were almost 16 million. That total is expected to reach 18 million by $2040^{31}$.

This slowdown in the rate of growth has been accompanied by significant changes in the composition of the population, as reflected in the changes in the so-called green and grey pressure. Fig. 8 shows that initially, the main change was that the green pressure (the ratio of the number of people aged 0 to 20 years to the number of people aged 20 to 65 years) began to decline sharply, until it more or less stabilised around 1990. At this point, the number of children stopped decreasing. Grey pressure (the ratio of the number of people over 65 to those in the 20-65 age group) remained low for a long time, but started to rise after the Second World War. An acceleration has been seen in recent years, and this is expected to continue in the years ahead. For example, for 2040 a value of 51 is calculated for grey pressure. That is almost double the current value, and indicates how heavy the associated tax burden is expected to

\footnotetext{
28 See e.g. International Monetary Fund (2017b), Staff Report for the article IV consultation The Netherlands, Washington, p. 9, and Organisation for Economic Cooperation and Development (2016), Economic Survey The Netherlands 2016, Paris, p. 11.

29 See also van Bavel (2016).

30 This fall in the LIS is an intriguing matter. In the 1970s, it was a key argument in favour of wage restraint. The continuing decline after 1980 therefore raises the question of whether that had a negative impact on domestic demand. Incidentally, this decline in the LIS occurs in many other countries. See for example.

31 See Statistics Netherlands (2016), Kernprognose 2016-2060: 18 miljoen inwoners in 2040 voorzien (Main demographic prognosis 2016-2060, 18 million inhabitants forecasted for 2040), The Hague.
} 


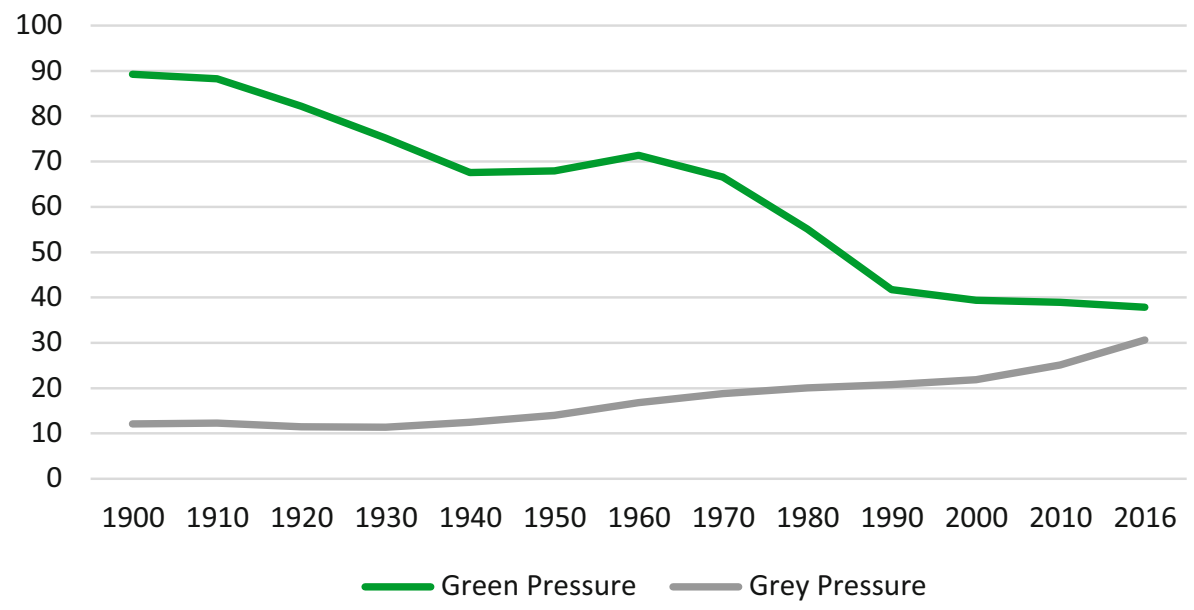

Fig. 8 Green and grey population pressure, 1900-2016. Source: Statistics Netherlands, Statline

be for working people at that time to cover the cost of pensions, social care and health care.

Another change in population composition concerns the scale of immigration. Whereas there was still a large negative migration balance in the $1950 \mathrm{~s}$, with many Dutch people emigrating to countries such as Canada and Australia, there has been a positive balance since the 1960 s, with occasional spikes followed by sharp downturns. Political, economic and social considerations have all played a role ${ }^{32}$. Particularly in periods of high influx, immigration has become more controversial, and the significance of Islam and the sharp rise in terrorist activities in the countries around us have also received increasing attention. At present, it is not possible to estimate how immigration will develop in the foreseeable future. It is clear that social acceptance towards taking in more migrants has been under pressure for some time, associated with many related problems in host countries, including the Netherlands. These concern matters such as education, the labour market, crime and involvement with the country of origin.

One further point must be mentioned here. The above-described demographic processes of slowing growth, changing population composition and ageing are not just found at national level: they are felt even more acutely at regional level. On the one hand there are regions with a shrinking population, mostly in the peripheral areas of a country; on the other hand, there are regions where the population is growing, partly through immigration from abroad, but also because of internal labour market migration. Education plays an important role here. This regional differentiation

\footnotetext{
32 Consider migration from Indonesia and Suriname, the first guest workers from Spain, Italy and Yugoslavia, the subsequent rapid growth of immigration from Turkey and Morocco, and in later years from many more countries in Africa and Asia, whether by asylum-seekers or those seeking to improve their economic situation. The latter motive is certainly also important for labour migrants from Central and Eastern European countries. For a long time it was assumed that these people had only come temporarily, but it is becoming increasingly clear that many are here to stay.
} 
occurs in the Netherlands, but even more strongly in the larger countries. I will come back to this point.

In conclusion, the demographic situation has undergone major changes in the post-war period, and these changes will continue in the foreseeable future. The initially strong population growth has continued to tail off, and is now approaching zero. First, the number of children dropped sharply, and now the age group between 20 and 65 has also peaked in absolute numbers. In the coming period, the number of people in that age group-and hence the potential labour force-will decrease. This in turn has consequences for tax and premium pressure. Taxes and premiums must then have to be paid by a smaller group, which puts their income under pressure. At the same time a strong increase in the group over 65 years can be expected. As a result, grey pressure will increase rapidly in the coming years, with the associated consequences for the financing of pensions and health care. In light of the already fierce debate about stagnant pension benefits and rising premiums, plenty of new developments can be expected in this area. The raising of the retirement age is inevitable, at least if pensions and health care for pensioners are to be maintained.

\subsection{Educational attainment level of the labour force}

One of the most striking and important changes that has occurred in the Netherlands in the past 60 years is the enormous increase in the educational attainment level of the labour force. Fig. 9 shows these changes for the labour force for the period 1960-2014 ${ }^{33}$. In 1960, 90\% of the Dutch labour force belonged to the lower-skilled category. By 2014, that share had dropped to $18 \%{ }^{34}$. The share of the medium-skilled initially increased, but has remained constant now for a while. The increase in the proportion of those with higher skills continues unabated, however. It is expected that this group will soon be the largest of the three.

Fig. 10 shows the same process for the last 15 years, but this time for the total population over the age of $15^{35}$. The previous graph concerned the labour force. This explains the relatively high share of those with lower skills in Fig. 10. The lower-skilled group's employment rate is significantly lower than that of the higherskilled. As a result, their share of the labour force is lower than their share of the total population ${ }^{36}$. The 15-year period is relatively short, but here too, the trend is clear. The proportion of the lower-skilled people decreases steadily during this period, from 40 to $32 \%$, that of those with medium levels of education remains more or less constant at around $30 \%$, and that of the higher-skilled rises from 20 to $28 \%$. Even in this short period, these are significant changes.

\footnotetext{
$33 \mathrm{http}: / /$ statline.cbs.nl/Statweb/publication/?DM=SLNL\&PA=80802ned\&D1=0\&D2=0\&D3=0\&D4=0\& D5=0\&D6=0-1,3-6,8-12,14-17\&D7=0-4\&D8=0-1,3,6,8,12,17,22,28,33-37\&VW=T.

34 In absolute terms, the decrease was less pronounced, from over 3.5 million to almost 1.4 million. The number of those with higher levels of educational attainment rose twentyfold.

35 See http://statline.cbs.nl/Statweb/publication/?DM=SLNL\&PA=82816ned\&D1=0\&D2=a\&D3=0\& D4=0\&D5=a\&D6=0\&D7=39,44,49,54,59\&HDR=G3, G2, G1, G6\&STB=G5, T, G4\&VW=T.

36 The cohort effect also plays a role: many older people were educated to a lower level, as we saw in Fig. 9.
} 


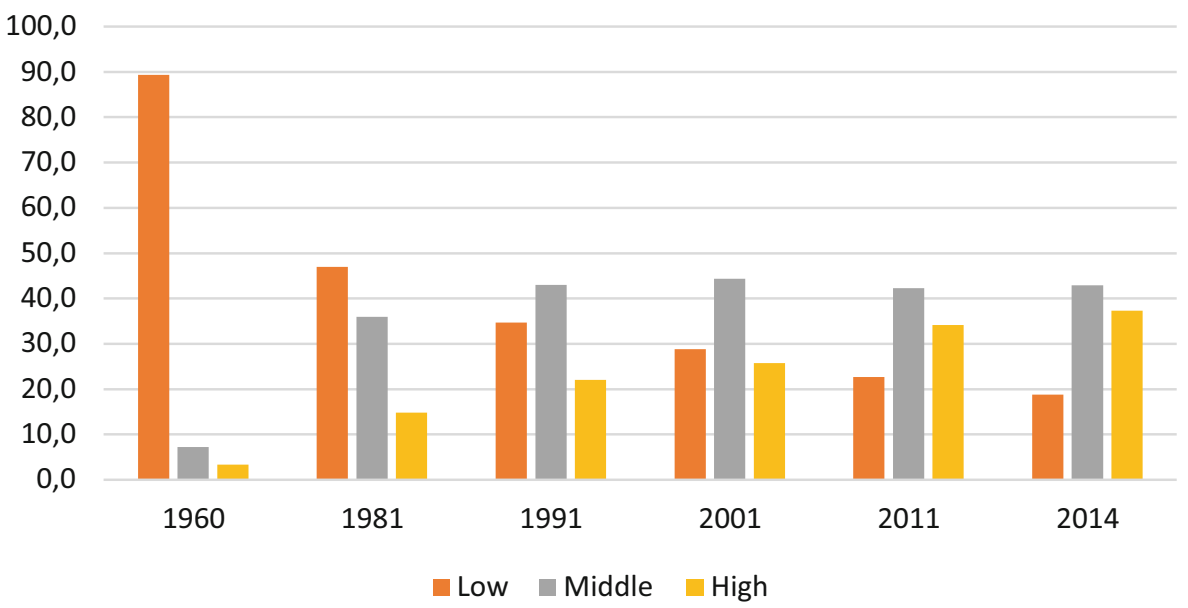

Fig. 9 Educational level of the labour force, 1960-2014. Source: CBS, see note 33

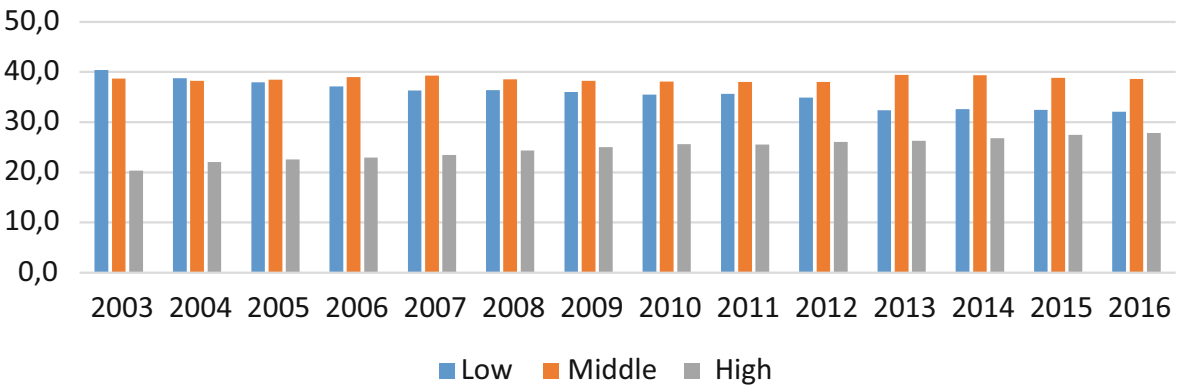

Fig. 10 Educational attainment level of the total population over the age of 15, 2003-2016. Source: CBS, see note 35

The sharp increase in those with higher skills in the last 60 years has been accompanied by the emergence of a more meritocratic society. In the past, it was not uncommon for social status or wealth to be decisive advantages for acquiring certain positions. Qualifications have now become much more important, not just in the labour market but elsewhere too ${ }^{37}$. At the same time, dedication, expertise, entrepreneurship and engagement remain important characteristics which are also widespread among the lower-skilled. Fortunately, there is still demand for their activities, and this makes it possible for many people to continue to earn a good living with a low level of education. But, crucially, not for as many as before. Many people are finding that their opportunities are diminishing, their position is under pressure, and they have become more vulnerable for economic events. This was already the case for those with lower levels of educational attainment, but it also increasingly appears to apply to the medium-skilled, and even the higher-skilled can be affected by it.

\footnotetext{
37 See Bovens and Wille (2017).
} 
Table 1 Net labour force participation, in people and in full-time units, 2003, 2010 and 2017

\begin{tabular}{lllllll}
\hline & \multicolumn{2}{l}{ Net participation in people } & \multicolumn{3}{c}{ Net participation in full-time units } \\
& 2003 & 2010 & 2017 & 2003 & 2010 & 2017 \\
\hline Low & 48.1 & 49.0 & 47.1 & 35.2 & 34.6 & 31.5 \\
Medium & 71.2 & 71.9 & 70.3 & 56.5 & 55.8 & 54.5 \\
High & 80.1 & 80.9 & 81.0 & 68.8 & 69.2 & 69.2 \\
Total & 64.2 & 66.7 & 66.7 & 51.0 & 52.4 & 52.2 \\
\hline
\end{tabular}

Source: Statistics Netherlands, Statline, and own calculations

Table 2 Permanent or flexible jobs, by educational level, 2003, 2010 and 2017

\begin{tabular}{lllllll}
\hline & \multicolumn{3}{l}{ Proportion of permanent jobs } & \multicolumn{3}{l}{ Proportion of flexible jobs } \\
& 2003 & 2010 & 2017 & 2003 & 2010 & 2017 \\
\hline Low & 79 & 71 & 64 & 21 & 29 & 36 \\
Medium & 85 & 80 & 73 & 15 & 20 & 27 \\
High & 88 & 86 & 81 & 12 & 14 & 19 \\
\hline
\end{tabular}

Source: Statistics Netherlands, Statline

It is useful to take a closer look at the development of the labour market in terms of level of education. Table 1 contains data ${ }^{38}$ on net labour force participation in the Netherlands, in persons and in full-time equivalents ${ }^{39}$. The differences according to educational level are substantial. The highly-skilled clearly have higher rates of employment than the low-skilled. This difference is even more significant when part-time jobs are taken into account. Converted into full-time units, 32\% of the potential working hours of people with a low level of education are used, compared with nearly $69 \%$ in the case of the highly educated. If the labour market is seen as the key to social cohesion, the low-skilled are increasingly falling by the wayside. The level of non-participation among them is growing ever higher.

In addition to the lower chance of employment, at the same time there also has been a significant increase in flexible forms of work, and here too, educational attainment level is a relevant factor. Table 2 shows the change over time per attainment level. It is clear that those with higher skills have always been more likely to have a permanent job, but the differences have increased significantly in recent years. Among the low-skilled, the decline was already noticeable between 2003 and 2010, and it seems to have accelerated since then. This acceleration can also be observed among the medium- and highly-skilled, but to a more limited extent. Not only is the number of jobs for the lower-skilled significantly lower, but far more of this smaller number consists of non-standard or flexible jobs. Based on these percentages, this would imply that, in 2017 , only $20 \%$ of the potential capacity of low-skilled workers

\footnotetext{
$38 \mathrm{http} / / /$ statline.cbs.nl/Statweb/publication/?DM=SLNL\&PA=82309ned \&D1=0, 2-23\&D2=0\&D3=0\& D4=1-3\&D5=4,34,69\&HDR=G1,G2,G3, T\&STB=G4\&VW=T.

39 Part-time work has been taken into account here. Part-time jobs have been converted into full-time units. On the basis of a 40-hour week, 4 people with a 10-hour job are treated as 1 full-time worker. The conversion factor is 0.25 for people with a job between 0 and $12 \mathrm{~h}$ per week, 0.4 for a job between 12 and $20 \mathrm{~h}, 0.6$ for a job between 20 and $28 \mathrm{~h}, 0.8$ for a job between 28 and $32 \mathrm{~h}$, and 1 for a full-time job.
} 
was being used in permanent, full-time positions, whereas for the highly-skilled, the total was $56 \%$. This is a big difference ${ }^{40}$. This situation is not conducive to social cohesion.

For a long time it was thought that for each labour market segment-low, medium and high - the demand for labour from employers and the supply of labour from workers would be fairly similar. The size of the labour market for the low-skilled was decreasing, that for those with higher skills was increasing, and that for those with a medium level of education remained more or less constant. Because the supply of workers seemed to be keeping pace with demand, it was thought that demand and supply could remain close to each other in each market segment ${ }^{41}$. This view can be found, for example, in the WRR report Tweedeling in perspectief $f^{42}$ from 1995. The press release announcing this report opened with the optimistic phrase 'Increased opportunities for harmonious development'. With hindsight, we can see that this conclusion was too optimistic. This is partly due to the fact that globalisation has occurred even faster since 1995 than was foreseen at that time, as a result of which more jobs at the low and medium skills levels have disappeared or are in the process of disappearing. But it is also because-again, due to globalisation-immigration has occurred on a larger scale than was expected at that time. The first generation of immigrants was certainly low-skilled. The result of this development was that there were more lower-skilled people than predicted, and at the same time fewer (permanent) jobs were available in that category than expected. This made it harder to hold onto a job or find a new job for the low-skilled, and to an extent for the medium-skilled too. The alternative was that these workers were compelled to take less secure, often flexible jobs, and also to accept a sluggish pay growth.

This impact of globalisation has gradually also reached the group of those with medium skills. Here too, many jobs have been lost, and the effects of lack of security has been felt by more and more people. The WRR also reported on this recently ${ }^{43}$. The gist of their exploration of this issue is twofold. On the one hand, the groups in the middle are so far not experiencing decline or erosion yet. At the same time, though, the exploration makes it clear that they have already made many sacrifices in terms of income, job security and prospects, and that measures are now needed

\footnotetext{
40 A recent Statistics Netherlands publication looked at the reasons why people were not working but were on benefits. Those with low levels of education between the ages of 15 and 65 are much more likely to be on benefits than the highly-skilled. The difference between the low-skilled and those from a non-Western migration background is relatively limited. This second group is also relatively low-skilled. In the first group, the share of those on disability benefit is somewhat higher, while the second group are more likely to be receiving social welfare benefits. In terms of other factors, such as studying or caring for the family or household or other reasons, the differences are limited. See Statistics Netherlands (2017), Helft nietwerkenden met uitkering kan/wil niet werken (Half of the non-working population on benefit can't work or does not want to work), The Hague, press release 7-10-2017.

41 Tinbergen even went so far as to foresee a future in which a sharp increase in the supply of higherskilled workers would lead to a relative decrease in their wages compared to the lower-skilled.

42 See Scientific Council for Government Policy WRR (1995), Tweedeling in perspectief (Social dichotomy in perspective), Report to the government, nr 50, The Hague: SDU.

43 See Scientific Council for Government Policy WRR (2017), De val van de middenklasse? Het stabiele en kwetsbare midden (The fall of the middle class? Stability and vulnerability in the middle segment of society), WRR Study, The Hague.
} 
to prevent a decline of the middle groups in income, jobs and status from occurring. That sounds less positive.

The conclusion must be that the pronounced increase in educational levels in the Dutch population has been one of the most radical socio-economic changes. This development has benefited many individuals in terms of income, job and competency development, and has certainly also been good for the national economy and society. The supply of those with higher skills has increased greatly, but so has the supply of suitable jobs for them. At the same time, the position of people at the bottom of the skills ladder has become more vulnerable. Although the labour supply in this segment has dropped sharply, employment opportunities have shrunk even faster, especially for permanent jobs. Globalisation and technological development have had a clear impact on this.

\subsection{Globalisation}

After economic growth and productivity, income distribution, demographics and educational attainment level, we will now consider a fifth factor which has had a major influence on the economic structure and society in recent times: this is globalisation - the growing significance of international economic relations. This development presents opportunities, but also threatens some groups. This section gives a global picture of globalisation based on a number of indicators for the Dutch economy: population, GNP, global trade and direct investment ${ }^{44}$. Global figures do show quite similar developments.

As a small, highly developed country surrounded by strong industrial powers, the Netherlands has always been closely connected to the global economy. That connectedness has increased further, as is clear from the following figures. Fig. 11 shows that the development of population, production and exports $(\mathrm{IH})$ for the Netherlands is comparable to their development in the global economy, although population growth and GNP growth are slightly lower. From this comparative viewpoint, exports have developed even more strongly. Here, as well as the downturn in 2009, the stagnation after 2000 is also noticeable. In Fig. 12, the considerable fluctuations in FDI are striking.

The Dutch economy has become more enmeshed with the global economy in the post-war period. This is true of international trade, and even more so of FDI. Thanks to these developments, the Netherlands has been able to take full advantage of economies of scale. From an economic point of view, the Netherlands occupies a fairly prominent position in global rankings, but in terms of population size we are clearly a small country. If Dutch companies also want to benefit from economies of scale, export markets are crucial. That is why European integration is so valuable for the Netherlands. It has created many new jobs, enabling companies and sectors to flourish. However, we should not close our eyes to the disadvantages. Greater integration also makes us more susceptible to developments from abroad. Companies,

44 The trade data are from World Bank Open Data, which can be found at http://data.worldbank.org/, FDI data from the United Nations Conference on Trade and Development (2016), World Investment Report 2010 and 2016, Geneva. 


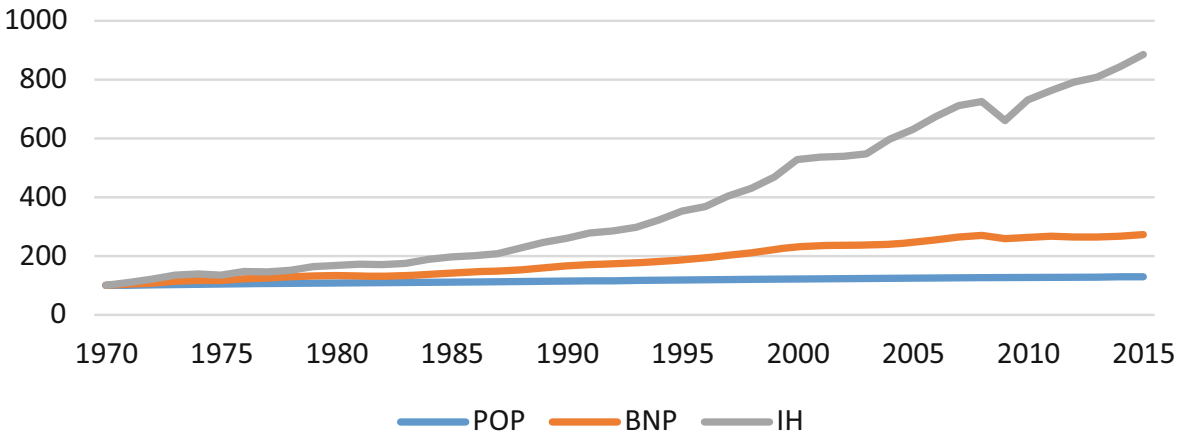

Fig. 11 Development of population, GNP and exports, 1970-2015. Source: see note 44

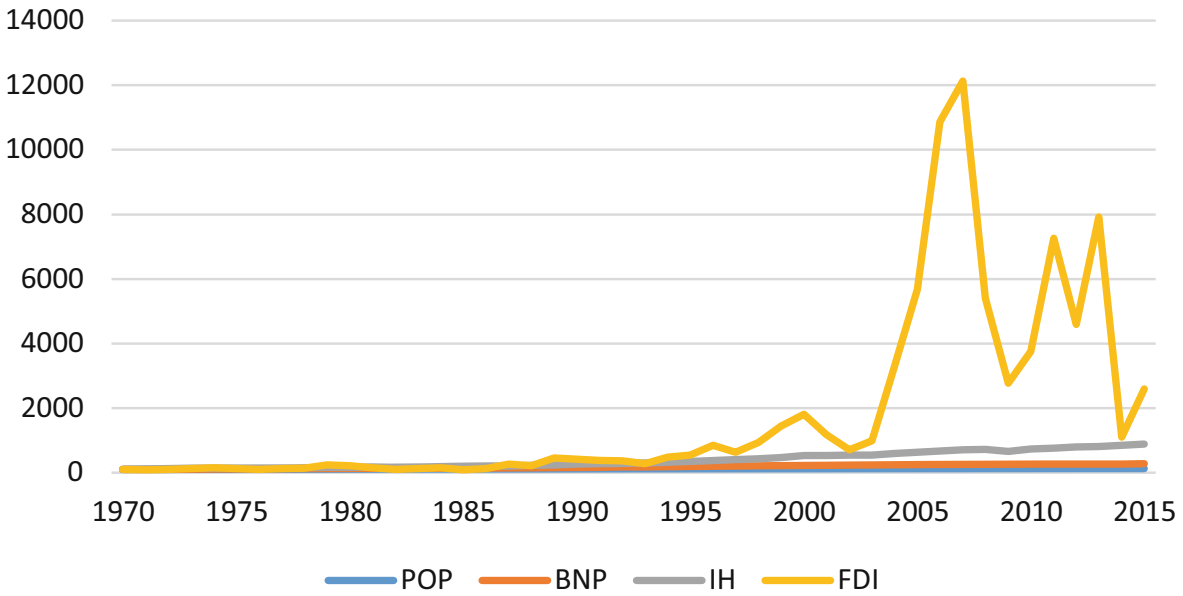

Fig. 12 Development of population, production and FDI for the Netherlands, 1970-2015. Source: see note 44

and sometimes whole sectors, disappear due to globalisation and technological development. As a result, jobs are lost. In order to remain competitive, the development of wage costs must be controlled, and hence the tax burden and premium pressure. This can lead to austerity measures for the welfare state, and hence less protection for the very group experiencing difficulties on the labour market. However positive the overall impact of globalisation and European integration is for the Netherlands as a whole, at an individual level there are losers.

\subsection{A cascade of changes}

Using five indicators, the development of the Dutch economy in the post-war period was described. The Netherlands has become much richer, as have its inhabitants, productivity has increased significantly, income distribution has hardly changed at the individual level, the educational level of the labour force has risen sharply, and globalisation has continued, accelerating in recent decades. 
All these developments are closely intertwined. Economic growth was closely linked to a marked catching-up phase in the years of post-war reconstruction. The baton was then partly taken over by strong growth in the educational level of the population and by continuing investments. Growth was also made possible by economies of scale and internationalisation. All in all, these processes have contributed greatly to the growth of prosperity, to the achievement of increasing labour force participation with generally moderate unemployment and a personal income distribution that was fairly egalitarian to start with and has stayed that way. A more positive picture would be hard to draw.

A second finding is that the period under consideration can be divided into two parts. In Part One, from around 1950 to 1980, there are remarkably high growth figures, with a very strong increase in productivity, slightly decreasing income inequality and a fairly stable internationalisation pattern. In Part Two, from 1980 onwards, growth is much more moderate, productivity growth is significantly lower and declining, income distribution does not become more equal and perhaps even increases slightly, and there is a clear acceleration in globalisation, especially in the case of FDI. The growth phase of reconstruction is followed by a more moderate phase with greater emphasis on internationalisation.

It is in the second phase that the divisions within society seem to have become greater; those divisions seem mainly to be due to the greater differences (and hence vulnerability) on the basis of level of educational attainment, and at the same time the influence of technological development and globalisation which, again on the basis of educational level, tend to erode the social distribution of work, income and prospects. Although many have been able to climb far up the social ladder, with all the associated advantages, thanks to better education, for a growing group of people the main increase has been in uncertainty - uncertainty about income both now and later on, about their current or desired job, about pensions, and about the future of their children. This uncertainty also translates into fear and anger, and is expressed as opposition to globalisation, European integration, banks, Islam and immigrants. Unfair though this may be, these things are seen by this group as a threat. This brings us back to the theme of this lecture, namely the delicate balance between economic change and social stability. Whereas in this section we have mainly looked at separate developments, in the following section we look more closely at how these developments fit together by means of a summary description of the post-war socio-economic development of the Dutch economy.

\section{The changing Netherlands}

Economic development is the result of economic growth, of technological development, of internationalisation, and of structural changes. What a company, sector or country can produce depends on the size and quality of the labour force, the available capital goods stock, institutional arrangements, the quality of government, entrepreneurship and relevant knowledge in such diverse areas as technology, organisation and marketing. Whether this potential production is actually realised depends on the demand for it at home and abroad, and that in turn depends on disposable 
income, price, design, quality, service, trade barriers and all the other considerations to which purchasers attach importance. All these factors influence the competitiveness of a company, a sector and, in aggregate, a country. It is very important for the supply side to constantly adapt to changing circumstances-changes in demand, technological developments, the rise and fall of competitors-here and elsewhere. The rule definitely holds good here that standing still means going backwards. At the same time, there must be sufficient demand for all those goods and services. Earned income is an important factor in this.

These supply-side changes do not happen of their own accord. Existing jobs change character and require new competencies and qualities. Sometimes they disappear, but new jobs also arise, in existing or new companies or sectors. To keep employment at its current level, or to reduce unemployment, not only jobs must be created: people also have to change jobs, either within or outside their own company, within or outside their own sector, and sometimes even within or outside of their own region. Changes in demand, technological developments and sectoral and regional shifts are key elements in the process of development. Globalisation and the growing significance of cross-border economic transactions, of goods and services, people and money, reinforce this pressure to adapt. As a result of these developments, requirements on the supply side in terms of expertise and competencies grow ever more stringent. As long as (potential) employees continue to develop their qualifications properly, there is no problem. Almost inevitably, though, some people will drop out. Situations then arise of the sort experienced increasingly frequency nowadays, in which companies are eagerly looking for people to fill vacancies, while at the same time many people are being side-lined: although they are willing to work $^{45}$, they are not recruited because of lacking competencies. Due to ongoing technological development and ever higher educational requirements, the chance of a mismatch is increasing all the time. Of course, some will object that labour force participation in many countries, and certainly in the Netherlands, has never been so high. This is true, not least because of the sharp increase in the women's participation in the labour force. But while the average level has continued to increase, as we also saw in the previous section, the differences in employment rates in terms of level of education have also grown ever greater. What is clear is that at the bottom of the skills ladder, prospects have become gloomier.

No matter how rational the decision to retain, change, scrap or relocate jobs is for companies, at the same time the outcome of that decision also has social consequences. Labour force participation means social engagement. People who are side-lined have more health problems, live shorter lives, have more social problems, are at greater risk of poverty for themselves and their children, are angrier with society, become less involved in democratic processes and more receptive to more radical views, and are more likely to come into contact with the judicial system.

\footnotetext{
45 Just to be clear, there are also people who are unwilling to work because of studying, illness, incapacity for work or old age, or sometimes because they are caring for the family or household. According to Statistics Netherlands, these factors account for $90 \%$ of those unwilling to work. See Statistics Netherlands (2017), Helft niet-werkenden met uitkering kan/wil niet werken (Half of the non-working population on benefit can't work or does not want to work), press release 7-10-2017, The Hague.
} 
Again, not everyone in this group fits this image, but the tendencies are there. When large numbers of people are unemployed, undesirable and negative social dynamics arise, with impoverished urban districts and people who have lost their homes. And if a real economic crisis breaks out as it did in 2008, it is precisely these people who are hit the hardest.

\subsection{The Netherlands under reconstruction, 1950-1980}

After the war, one thing was clear in many countries, including the Netherlands. Never again there should be a crisis again of the kind experienced in the 1930s, with its poverty, desperation and political aberrations. In Western Europe, this resolve was translated after 1945 into a social order in which the market with its privatesector production was the centre-point, but where at the same time the government assumed responsibility for providing those who (temporarily) were unable to earn an income due to illness, incapacity for work, unemployment, old age or other reasons, with at least basic income support and, if possible, help finding a job elsewhere. The government provided all kinds of support, such as retraining and relocation premiums, to guide people into new jobs as best it could. As the welfare state was constructed, these risks for individuals were reduced to a significant extent.

During the same period in which the welfare state was being constructed, from the early 1950 s to the early 1970 s, the development of the Dutch economy was very strong. For the Netherlands, as for almost all Western European countries, the 1950s and 1960s were exceptional in socio-economic terms ${ }^{46}$. This strong economic development was accompanied by far-reaching adjustments ${ }^{47}$. For instance, employment in the agricultural sector fell sharply, by almost 300,000 jobs or $50 \%$ in 20 years, while at the same time a strong industrial development was experienced. The port of Rotterdam with its oil and chemical industry underwent rapid growth. Large-scale national migration occurred, from the North and Southwest of the Netherlands to the Western part, to the Randstad. At the same time, many jobs were added in the construction sector due to the demand for housing and infrastructure. More and more young Dutch people opted for higher education. Looking back, it is striking how relatively smoothly all these radical changes were able to take place. What is certainly true is that the emerging welfare state was no impediment to these adjustments.

These changes were closely linked to extensive internationalisation. For a small country like the Netherlands, this was and is an essential option. Only in this way can we benefit adequately from economies of scale and larger markets on which to sell our products. In order to make the most of this extensive internationalisation, during those years there was a strong emphasis in socio-economic policy in the Netherlands on productivity improvement and wage restraint. As a result, exports grew rapidly, with all the associated positive consequences for employment and incomes. This internationalisation took place in an international context - that of the Pax Americana-also characterised by profound change. It was not just at the national level

\footnotetext{
46 This observation holds true for virtually all Western countries.

47 See Schuyt and Taverne (2000), 1950, Welvaart in zwart-wit: de Nederlandse wederopbouw in 12 beelden (Growth in black and white: The Netherlands post-war reconstruction in 12 images), The Hague: Sdu.
} 
that people had learned lessons from the crisis of the 1930s: this had also happened internationally. Protectionism and beggar-thy-neighbour exchange rate adjustments of the sort that had occurred during the crisis years had to be prevented. With the Pax Americana, clear rules governing international economic relations were introduced. Trade barriers were quickly dismantled, a system of fixed but adjustable exchange rates was established and worked well for a long time, and international capital movements were also possible to an appropriate degree. European integration got off the ground smoothly, with all the benefits that this entailed. In addition, there was the rise of new competitors such as Japan, South Korea, Taiwan and Hong Kong. In short, internationally, there was dynamism everywhere.

As a result of all these changes, the Dutch economy in 1980 was very different from in 1950, in terms of structure, technology, productivity and internationalisation, and hence in terms of income and employment, but these changes took place relatively smoothly, thanks in part to the national and international institutions and rules. Considered over the entire period, it is fair to say that there was a good balance between challenge and protection, between innovation and security, between growth and change.

\subsection{The internationalising Netherlands, 1980-2017}

All of this sounds positive, and taking the entire period into account, this is a valid conclusion. However, it obscures the fact that at the end of this period the social balance had started to slip. The closure of the mines, the demise of the textile industry and the problems in sectors like shipbuilding made it clear at the end of the 1960s that these substantial adjustments were increasingly outstripping the resilience of society and institutions. With the oil crisis of 1973 and then that of 1980, many countries, including the Netherlands, were strongly hit by a severe economic crisis. Unemployment rose sharply in the 1970 s and 1980 s, to above $9 \%{ }^{48}$, growth stagnated (with the economy even shrinking in 1982), and fiscal equilibrium was disrupted (the deficit was $6 \%$ and the debt ratio increased to $75 \%$ ). The funding of the welfare state was certainly implicated in this. Wonderful though all the welfare support schemes were, the premiums for them ensured high labour costs and therefore undermined competitiveness ${ }^{49}$. Despite all these red signals, the existing economic policy was initially held onto. After all, this policy had gone well for a long time. Why might not that glorious reconstruction phase return? After a number of years, however, the problems had become so serious that something had to be done. The Lubbers-I government saw a change of policy. A series of solutions was tried, initially focusing primarily on adjustments to the economic structure ${ }^{50}$, but with an

\footnotetext{
48 This only included those officially out of work - a total of 600,000 people. People receiving social assistance (numbers of whom rapidly rose to 500,000) and especially work incapacity benefits (more than 600,000 in the early 1980s, and rising), who could also be considered as partially unemployed, are not included in the figure.

49 It is no coincidence that in those years the Invalidity Insurance Act was used by many companies to provide older, less productive employees with a relatively favourable deal.

50 See Scientific Council for Government Policy WRR (1980), Plaats en toekomst van de Nederlandse industrie (Industry in the Netherlands: its place and future), The Hague, Staatsuitgeverij.
} 
increasing emphasis on the cost side ${ }^{51}$. With the changes in the United States and the United Kingdom in mind, the Netherlands also put more emphasis on market forces, deregulation and privatisation ${ }^{52}$. At the same time, renewed attention was paid to wage restraint. The welfare state did not escape change either. In the social security system, many schemes were adjusted after 1980, benefits were reduced and their duration was shortened. Much also changed in labour market policy. At first there was little belief that this policy would succeed, but from the early 1990s the economic motor really got going in the Netherlands. Growth rates increased dramatically, employment perhaps even more so, and unemployment fell sharply. While collective bargaining remained restrained, equity and house prices began to rise.

It was not only the national context that changed strongly during the 1980s and '90s: the same dynamism was seen internationally. There too, liberalisation became increasingly widespread. This process began in the 1980s, but with the fall of the Berlin Wall and the collapse of the centrally planned economies, only one creed of economic order remained: that of the market with liberalised economic relations. In trade in goods and services, further tariff reductions occurred and markets also became increasingly open in other ways. Much of this had already been achieved after the war-the really big change in the 1980s was the radical liberalisation of cross-border capital flows. Suddenly, financial markets were no longer national, but global. The free market's praises were now being sung on all sides. At the same time, the financial market itself was also changing strongly. Thanks in part to IT, many new, often risky financial products could be developed. As with a pyramid scheme, more and more players entered, who also wanted to take advantage. It seemed as though nothing could go wrong. There were also fewer supervisory bodies to give warning, their capacity having been greatly reduced by deregulation ${ }^{53}$. There were crises, but these were handled fairly smoothly. For many years, things went well, and high returns were realised. Then, in 2008, things went badly wrong. We have struggled with the consequences of this over the last nine years.

There was also very strong growth in FDI. Chain production became ever easier to organise. FDI from the richer countries to Central and Eastern Europe, China and Southeast Asia led to job losses here. All these changes contributed to the economic development of many countries, but at the same time created more uncertainty, precisely among those in Western Europe who felt already insecure.

Within the European Union too, liberalism continued unabated. In the late 1980s, it was decided to create a proper internal market, with free movement for goods, services, capital and people. EMU was launched in 1999, the euro was introduced in 2002, and 2004 saw the accession of ten Eastern European countries to the European Union. The freedom of movement of people subsequently led to considerable labour migration from those countries to Western Europe. In the Netherlands, these

\footnotetext{
51 See Wagner Commission (1981), Een nieuw industrieel elan (A new industrial elan), The Hague.

52 It is reasonable to ask whether the Netherlands and other countries actually had any choice. What would have happened if the existing policy had been maintained?

53 For the consequences of this in the German banking sector, and the inability to learn lessons, see M. Hellwig (2017), Deutschland und die Finanzkrise(n), Wirtschaftsdienst, 97(9), 606-607.
} 
developments were long regarded as positive, but this optimism was also apparent in other countries. More market had delivered more prosperity, more work, more growth. Despite wage restraint, the growth of the phenomenon of two-income households and rising share and house prices led to a positive mood. Due to rising share prices, pension premiums did not rise that strong. Although globalisation, the Internet and other technological innovations led to more imports and to job losses, so many new jobs were created that unemployment fell significantly and labour market participation rose sharply. The 1990s were great years. These favourable economic results were also recorded abroad, and the Polder-model became a shining example.

What was neglected, however, was that there were also losers, losers who got less and less protection. Cuts had been made to the welfare system, partly in order to lower the tax and premium pressure. This was necessary in order to improve our competitiveness with other countries. And of course disability benefit claims had increased far faster than those who devised the scheme had thought possible. After the exuberant growth of the 1960s, retrenchment was an entirely realistic option. The growth in the 1990s had been achieved partly through strong growth in employment, and partly through a much stricter volume and price policy. The labour market was becoming more flexible, reducing fixed employment for certain groups, while at the same time the welfare state offered less protection in terms of benefits and reintegration possibilities. The level of benefits did not keep pace with income development generally, and the length of the regular benefit payment period became shorter in many cases. While many jobs were lost and new, stable jobs became harder to find, income development was under pressure. The increased dynamism, partly reinforced by technology and globalisation, put up the number of those who lost out, who also found that their protection by the national government was diminishing. This discovery did nothing to help large numbers of citizens to place confidence in globalisation and European integration.

Looking at the whole period from 1982 onwards, there are many positive developments, but it is clear that also a price has been paid. There have been significant structural changes, especially in the labour market. Due to stagnating real income development, strong growth in all kinds of flexible work, uncertainty about pensions and benefits and the sharp decline in house prices, many people's situation became more uncertain after 2008. The relationship between economic adjustment and social stability described earlier seems to have become unbalanced, to growing dissatisfaction in some quarters. For the sake of clarity, the developments outlined here are not exclusively Dutch: on the contrary, they are characteristic of many countries in the Western world. The choice in favour of Brexit and Trump, which looks irrational to many eyes, illustrates this.

\subsection{The overstretched government?}

In this context, it is helpful to turn back to a somewhat older preliminary study of the WRR from 1995, entitled Staat in beweging ('The State in Motion') ${ }^{54}$. This study focused on the function and functioning of state and government. It was argued that

54 Scientific Council for Government Policy WRR (1998), Staat in beweging (The state in motion), The Hague, Report no 100. 
three areas of tension were arising within current social developments with which the government might increasingly have to deal. These were:

1. Ensuring some degree of certainty against a background of market dynamism and expansion

2. Developing the national capacity for action against a background of internationalisation, including on the part of governments, and

3. Protecting social equality against a background of individualisation, internationalisation and dynamism.

Certainty, capacity for action and equality are three central aspects in the functioning of a government. As the preceding description has made clear, these aspects have come under pressure. The certainty or confidence with which governments in the 1950s and 1960s seemed to be able to stimulate economic development with almost full employment took a serious knock in the 1970s. Although there was some recovery afterwards, confidence about the future is a thing of the past for a growing number of people. In the post-war period of recovery, the chosen economic order, featuring market forces but also protection when needed, seemed able to offer both the desired dynamism and the desired protection for those unable to keep up. The mix of neoclassical and Keynesian notions provided the government, including in the Netherlands, with an aura of decisiveness and protectiveness. That aura has largely been lost in recent years. Even if the government wished to do so, it seems almost impossible to organise proper protection for those who have lost out. And to make matters worse, the pursuit of social equality has also come under pressure. Under the influence of individualisation, reinforced by much higher levels of education on the part of more and more people, by internationalisation and by the dynamism associated with all these developments, the trend towards inequality has increased. Inequality in training, in labour market opportunities, and in income. This raises the question of whether globalisation has played a role in these developments, and if so, whether that delicate balance has been lost as a result.

\section{On dynamism, globalisation, social uncertainty and populism ${ }^{55}$}

\subsection{What does history teach us?}

It is primarily the interplay of globalisation and technology, in an increasingly liberal environment, that has created a strong economic dynamism in the last 30 years $^{56}$. Thanks to breakthroughs in transport technology (from the steamship via rail to the car and later the container) and communication technology, transport and com-

\footnotetext{
55 This section is partly based on a recent article by Dani Rodrik: D. Rodrik (2017), Populism and the economics of globalization, NBER Discussion paper 12119, Cambridge.

56 For a good overview, see Organisation for Economic Cooperation and Development (2017), How technology and globalisation are transforming the labour market, in Organisation for Economic Cooperation and Development (2017) Employment Outlook 2017, Paris, chapter 3, pp. 81-124.
} 
munication costs have fallen dramatically ${ }^{57}$. To this has been added the mobility of knowledge. With global value chains, cross-border production processes within companies have become increasingly important. All this has ensured that globalisation has become more extensive, unexpected, individual and hard to predict. It is precisely this dynamism and its unexpected, sometimes unfair distribution of the consequences of globalisation that have contributed to the recent feelings of social unrest.

\subsection{Globalisation is a good thing overall}

We can now take a more detailed look at the pros and cons of globalisation. Thanks to new technology and globalisation, labour productivity is increasing, products are becoming cheaper, more and better products can be manufactured with the same number of people, there is a wider range of products available, and incomes are improving. Of course, there are people who lose jobs or income as a result of globalisation, but if the winners of that development should compensate all losers, the overall assessment is positive. Redistribution through taxes and benefits in the context of social security is therefore a sensible option. However, the point still holds true that we achieve progress in aggregate. This is not just the result of a wide range of economic models: it also refers to actual developments, as described above in various ways, such as Milanovic's graph and the growth figures in the post-war period.

The liberalisation of capital flows also presents numerous advantages in theory. These include wider availability of finances in less developed countries, lower costs and lower interest rates on the global markets and therefore more investments, more opportunities for exports and, for many, a higher income. At a global level, better inter-temporal allocation of investments and consumption is possible, which is not without importance for ensuring the future funding of pensions. Finally, this development offers better opportunities for portfolio diversification, for example for pension funds.

In addition to goods, services and capital, there is the freedom of workers to move across borders. Whereas in the past almost everyone was low-skilled, and many immigrants were able to quickly enter the labour market, higher levels of education at the domestic market and the associated disappearance of many relatively simple jobs have made this much harder to do for immigrants without adequate training, without a good knowledge of the language and without relevant competencies.

Technological development and globalisation have brought us great prosperity and new prospects. Both issues contributed greatly to the unparalleled income development after the war. But there are also disadvantages and people who have lost out. These negative consequences have become clearer in recent times. A broader look at the downsides of globalisation is needed.

\footnotetext{
57 See R. Baldwin (2016), The Great Convergence, information technology and the new globalization, Cambridge: Belknap Press.
} 


\subsection{But there are also downsides to globalisation}

These downsides have been known for much longer. Rodrik presents his argument about ${ }^{58}$ the disadvantages of globalisation on the basis of the long-established Stolper-Samuelson theorem. A situation is assumed in which there are two countries, two goods and two production factors. Both products can be made in both countries, implying that self-sufficiency is also an option. Trade will arise at some point, for example due to the lowering of trade barriers. At that moment, the importing of a product will ensure that part of the domestic production of the same product will cease. This will also mean that jobs are lost. Ideally, the workers who have lost these jobs will be employed in the other sector. If it is further assumed that there are two types of labour, lower- and higher-skilled, it must be borne in mind that the low-skilled workers will be worse affected. This is because the relocation of production is often due to lower (wage) costs elsewhere. And if those with higher skills levels become more affected, they can be expected to compete with lowerskilled for the remaining jobs. In both cases, the lower-skilled are worse off. This means that they will lose their jobs, and as a result, the supply of lower-skilled people on the labour market will increase. This exerts a downward pressure on the wages of this group. At the same time, the relative price of the specific domestic product will also fall. All these changes mean a redistribution of jobs and income, in favour of the less affected group. As the trade barriers are lowered further, the effect of this redistribution will increase, while at the same time the net benefits of the extra trade will decrease. Liberalisation of international trade shows decreasing returns-in the initial phase, strong productivity improvements are possible, but as imports continue to increase, this effect becomes smaller-and at the same time the redistribution costs increase. In addition, there are the costs of disruptions due to higher taxes and premiums to compensate those who have lost out, and transfer costs. All this means that globalisation will have clearly positive results in the initial phase, but that its benefits will decrease as liberalisation is pursued further. As costs mount ever higher, the additional benefits grow fewer and fewer.

On this basis, it can be concluded that although international trade has a positive effect on a country's economic growth, specific groups may suffer from a fall in income and lose their jobs, and that income inequality may increase at national level as a result. And that, in turn, adversely affects social trust ${ }^{59}$. These side-effects of international trade are known. When trade agreements are concluded or decisions taken about direct investment, there is often a clause about compensation measures, ranging from severance schemes for employees who lose their jobs to an additional boost for new employment through regional policy. In many cases, the implementation of such measures is meagre at best. More often, especially in European countries with a welfare state, compensation takes place through generic social security schemes. That is a positive difference between many European countries and the United States, where such protection does not exist to the same extent. Yet

\footnotetext{
58 See Rodrik (2017), pp. 5-7.

59 In this connection, see also a study by Citi GPS and Oxford Martin School (2017), Inequality and prosperity in the industrialized world. Addressing a growing challenge, London.
} 
here too, those who are affected see their incomes decline over time, while additional spending tends to lead to higher taxes and premiums, which in turn is detrimental to other companies and to competitiveness. At the same time, in a globalising world, trade unions undeniably have fewer and fewer opportunities to enforce adequate compensation for the workers affected.

In addition, and this further exacerbates the problem, global winner-takes-all situations are becoming increasingly common. Google, Apple, Uber and similar companies illustrate this point. In the past, there was usually a catching-up process and a cross-border product life cycle. After being initially used in its country of origin, technological knowledge could then also be used elsewhere, also by other companies, for example because lower wage costs made reallocation of production attractive, or because consumers elsewhere became interested in that product too. Now, however, the winners immediately win the whole market, and there is hardly any room left for competition. Of course companies such as Google also provide jobs here, but at the same time governments find them more intractable and have greater difficulty in getting them to share in the costs of this type of process as well as the benefits.

The liberalisation of capital movements creates both advantages and disadvantages in other ways ${ }^{60}$. Ostry et al. make it clear that the liberalisation of financial flows has a positive impact in terms of FDI. This is true of decisions of a long-term nature; where short-term financial transactions are concerned, for example when adjustments are desired in the portfolio of investment companies or in relation to speculation, the downside is much greater, because of the related volatility. This increases the probability of financial crises. For a long time, it was thought that this effect was mainly important in countries with a less developed financial system, and therefore could not occur here, but the crisis of 2008 has made it clear that even in developed countries, banks and the financial system can take a serious battering from these short-term financial flows. Such flows also push income inequality up and the LIS down, while as a result the tax burden necessarily ends up weighing ever more heavily on the production factor of labour. This in turn has a negative effect on employment and growth.

In light of this, one can see why, after the Second World War and until the mid1980s, it was decided to apply a fairly restrictive policy on cross-border capital flows. People were worried that crisis situations like those in the 1930s could otherwise easily arise again. It was also felt that this restrictive policy would counteract volatility and create more space for appropriate national macroeconomic demand policies. But these restrictions were completely washed away by the liberalisation tidal wave of the early 1980s. Things could get better and had to get better, and free markets were the right way to ensure this happened, including for capital. Since then, volatility on financial markets has clearly increased, with the dramatic crisis in 2008 as an extreme manifestation. According to Reinhardt and Rogoff, there is

${ }^{60}$ See J.D. Ostry, P. Lougani and D. Furceri (2016), Neoliberalism oversold?, IMF Finance \& Development, June 2016, pp. 38-41. 
a perfect correlation between financial globalisation and economic crises ${ }^{61}$, which are now also affecting the financial markets in developed countries. It is therefore understandable that the IMF has abandoned its position that any control over capital movements is wrong. People are now more inclined to mention the benefits of capital controls. Recently, Mallaby argued that the downwards shift in the trend of financial globalisation might even be economically healthier ${ }^{62}$. The growth in FDI should continue, however, according to Mallaby.

Regarding cross-border flows of persons, of labor, views differ greatly on the economic contributions of migration. On the one hand, the desirability is pointed out of keeping the national labour force at least at the same level in absolute terms and thus also alleviating the burden of future pension payments; on the other hand, it is argued that the cost-benefit balance of the lifetime income of immigrants is taken into account ${ }^{63}$. At a socio-cultural level, opinions on the desirability of immigration also differ, but negative assessments have been more prominent here. Many people, especially the lower-skilled, have experienced competition from immigrants in the labour and housing markets. In addition, many of the original occupants of areas where many immigrants have moved in have had the sense of losing a familiar environment. It is striking, however, that the loss of jobs through FDI has often been felt less acutely than the influx of immigrants who have taken jobs here. From a cultural perspective, the distinction between production there and here is of course more significant. For those groups that, because of the economic dynamism described-with growing skills differentiation, the influence of globalisation and decreasing demand for their capabilities — are already under pressure, immigration means fewer opportunities.

Globalisation also affects government budgets. The 2008 crisis showed how vulnerable national economies, including that of the United States, are to global crises. The fall of Lehman Brothers caused an unprecedented chain reaction, in which numerous banks had to be nationalised in just a few weeks, and other forms of substantial financial support were also needed to keep banks and financial markets afloat. The impact of this crisis in the months that followed, with a sharp downturn in production and international trade, led to a sharp fall in GNP, with less tax revenue and increased government spending (due to rising unemployment). The result was sharply rising deficits and government debt. Given the need to remain competitive, that deficit could only be tackled through substantial spending cuts. Polyakova and Fligstein do show that in the countries where the effects of the 2008 financial crisis were most apparent, support for a more national identity has increased, at the expense of European identity. Citizens who take this view believe that the EU has done nothing to protect them since the crisis, and this has led to a stronger attachment to

\footnotetext{
61 See C.M. Reinhardt and K.S. Rogoff (2011), This Time Is Different, Eight Centuries of Financial Folly, Princeton: Princeton University Press.

62 See S. Mallaby (2016), Globalization resets, Finance and Development, 53(4), 6-10.

63 We should not lose sight here of the fact that the structure of the welfare state is also significant. In the United States you see more immigrants who have successful careers. Steve Jobs is a good example.
} 
their individual state ${ }^{64}$. Dwindling growth has in turn also boosted populism, with support for the traditional central parties crumbling away in favour of more extreme views. At the same time, populism itself has an adverse effect on economic development, in the short term because it exploits resistance to change, and in the longer term because productivity development is slowed down further. National economies also become even more sensitive to cyclical fluctuations ${ }^{65}$.

\subsection{Is the final assessment positive?}

The analysis in the previous section shows that globalisation certainly has major disadvantages. The most important point is that international trade and migration flows can be detrimental to the most vulnerable production factor, which in the present situation is lower-skilled labor. Can, because lost jobs can be replaced elsewhere and average productivity and hence the wage rate could increase. But it would require extra training and retraining, switching to a new employer, and in some cases relocation too. This pattern worked in many countries in the period up to 1980 more or less properly. But thereafter this pattern worked less fluently. While globalisation increased, with more international trade and more FDI, job losses multiplied and the supply of suitable jobs for lower educated people shrank at the same time. As a result, their bargaining power declined, leading to stagnating wage growth and more flexible employment conditions. Increased immigration, itself a consequence of globalisation, made their position even harder. At the macro level, globalisation caused greater income inequality and a declining Labor Income Share. The degree of redistribution through taxes and social security too came under pressure, because of the same globalisation. More investment in education could have counteracted some of these negative consequences, but again, the budgetary restrictions became increasingly stricter. Tax rates for mobile production factors such as capital, but increasingly for labour too, came under pressure. The liberalisation of capital flows contributed to a more volatile climate on financial markets, resulting in more economic recessions. Together with the creation of all sorts of new financial products and less supervision, these were further ingredients for a financial economic crisis of the kind that occurred in 2007.

After 1980 the costs of the globalisation process have increased over time, and are unevenly distributed across society. Certain groups have been hit harder than others. The existing adjustment mechanisms, from social security to employment agencies, have been unable to compensate these losses properly. And little attention has been paid to the need to do so in any case. Economists are partly to blame for this. With every liberalisation of international economic relations, the emphasis has been placed too exclusively on the potential growth it could bring about. The fact that there were also costs has received far less attention, and even less consideration has been given to the question of who would feel these costs and what compensation

\footnotetext{
64 See A. Polyakova and N. Fligstein (2016), Is European integration causing Europe to become more nationalist? Evidence from the 2007-2009 financial crisis, Journal of European Public Policy, 23(1), 60-83. 65 See World Bank Group (2016) Polarization and populism, Washington: Europe and Central Asia economic update, November 2016.
} 
would be possible. In a recent article in Brookings Papers, Philippon ${ }^{66}$ states that this one-sided view has contributed to the public's growing distrust of economists and economic models.

This one-sided focus on the benefits of globalisation alone is now starting to change cautiously ${ }^{67}$. The December 2016 edition of the IMF magazine Finance \& Development was devoted to the position of insiders and outsiders in the process of globalisation. For example, Obstfeld, director of research at the IMF, argued for the importance of a better redistribution of benefits to affected groups in a society ${ }^{68}$. Krugman also states, based on the same graph of Milanovic as at the start of this article, that while the balance may be positive, there are also losers. If the current turmoil led to a temporary halt in the conclusion of new trade agreements, he would not regard that as too drastic a consequence. The marginal benefits of these agreements are so slight that they do not outweigh the risks of a trade war in any form whatsoever ${ }^{69}$. What would be much worse, argues Krugman, would be a situation where hard-line protectionist views were implemented, with (much) higher tariffs or closed borders.

An attempt to work out more concrete suggestions on how the losers of globalisation could be compensated, can be found in a recent article by Südekum ${ }^{70}$. He too is convinced that it is especially the lower-skilled who are among the losers. The problem, though, is that it is not so easy to identify winners and losers, and to work out the extent of gain or loss. Of course there are the current arrangements of progressive taxation and benefits via social security, and these should certainly continue. However, the margins are small, and further tax increases are likely to act as a brake on growth. An alternative would be to set up a separate fund, a so-called Trade Adjustment Assistance Fund, from which people who become unemployed due to globalisation can be retrained directly for other jobs. Here too, though, it is unclear whether people lost their job because of globalisation, or because of new technology, digitalisation or declining demand, or simply because they had become unproductive.

Businesses are also starting to talk about this problem. For instance, Boston Consulting Group recently published a report entitled Inclusiveness: in everyone's interest $^{71}$. In their analysis, they state that although globalisation provides more income, if not everyone benefits, as is currently the case, resistance to it and hence calls for protection will increase, with all the negative consequences for growth and employment opportunities. In their opinion, the income consequences in the

\footnotetext{
66 See T. Philippon (2017), Brexit and the end of the great policy moderation, Brookings Papers on Economic Activity, Fall 2016, pp. 385-393.

67 A separate section is also devoted to this problem in the latest Budget Memorandum. See Ministry of Finance (2017), Miljoenennota 2018 (Government Budget 2018), The Hague, Sect. 2.5.

68 See Obstfeld (2016), Get on track with trade, Finance and Development, 53(4), 12-16.

69 See Krugman (2016), Leave Zombies Be, Finance and Development, 53(4), 11.

70 See Südekum (2017), Die Globalisierungsverlierer kompensieren - aber wie?, Wirtschaftsdienst, 97(8), $566-570$.

71 See Boston Consulting Group (2016), Inclusiviteit: in ieders belang. Een prioriteit voor politiek en bedrijfsleven (Inclusiveness: important for all. Priority for politics and business), Amsterdam.
} 
Netherlands are limited, but there is much more of a problem with the growing uncertainty about income, finding or holding onto a job, and the level of protection in the event of redundancy.

\subsection{What are the social repercussions of globalisation?}

Once again, globalisation has brought many benefits both globally and nationally. There is no reason to fence national economies off from the wicked outside world through closed borders. These economies themselves will suffer the most from doing so. The different scenarios with regard to the consequences of Brexit clearly show this. But at the same time the latent discontent, the negative aspects of economic and social development, has to be taken better into account. If not, a high price economically and politically can be paid.

In recent years, there have been numerous studies of the rise of populism and the possible connection with globalisation and technological development. The Bertelsmann Stiftung has explored these processes in a number of reports. In its report Wohlstand für alle, the socio-economic development of Germany after the Second World War was examined. Three periods were distinguished: the Wirtschaftswunder (1949-1966), demand orientation (1967-1982), and supply orientation (from $1983)^{72}$. While inequality declined across the board in the first two periods, it has risen again in the last period. This has created growing inequality in personal income distribution. In addition, regional differences have increased, with some regions being hit harder than others by the impact of company closures. While the German economy recovered strongly after 2005, this was not noticeable for the lower income groups. Fratzscher likewise takes the view that income inequality in Germany has increased in recent years due to a poorly functioning soziale Marktwirtschaft ${ }^{73}$.

At the end of 2016, the Bertelsmann Stiftung also published the results of a survey in the $\mathrm{EU}^{74}$ which clearly showed that a large group in society $(45 \%)$ saw globalisation as a threat rather than an opportunity. These were mainly people with lower incomes, the lower-skilled and older people. It is precisely these people who want to leave the EU and who have built up a lot of distrust of politics, politicians and political parties. People feel that they are excluded and not listened to, and naturally this affects the political choices they make.

The political consequences of social discontent are also considered in a comprehensive study by Barclays entitled The politics of rage $e^{75}$. The title leaves little to the imagination. In many countries, a collapse of the political centre is being observed, coupled with the (sometimes fragmented) growth of parties with more

\footnotetext{
72 See Bertelsmann Stiftung (2017), Wohlstand für alle. Wie inklusiv ist die soziale Marktwirtschaft?, Gütersloh.

73 See Fratzscher (2016a), Hohe Ungleichheit durch schlecht funktionierende soziale Marktwirtschaft, Wirtschaftsdienst, 96(6), 583-588, and Fratzscher (2016b), Verteilungskampf - Warum Deutschland immer ungleicher wird, Munich: Carl Hanser Verlag.

74 See Bertelsmann Stiftung (2016), Europäer nehmen Globalisierungsängste mit in die Wahlkabine, EUPINIONS, 30-11-2016.

75 See Barclays (2015), The politics of rage, London.
} 
extreme views. This process has been going on for a long time. The influence of globalisation, especially in trade and immigration, and growing income inequality are certainly factors in this, but more important is the sense of those who have lost out that national politicians no longer care about the consequences for them. They believe they have been ignored by the elite. What further reinforces their distrust is the offloading of responsibilities onto international bodies. The researchers expect this anger to increase further, partly because national politics seems incapable of addressing these errors. Focusing exclusively on taxes and social security is not enough. These people are more interested in restoring national sovereignty, political reforms, immigration and trade restrictions and tackling multinationals. It seems a good description of the situation in the UK and a useful explanation for Brexit, but be aware: this kind of anger is less prominent in the UK than in many continental EU member states, according to the researchers.

Winkler also stresses political impotence in his conclusions ${ }^{76}$. In his view, a social model (the soziale Marktwirtschaft) was developed in Germany after the Second World War, in which more conservative notions about the nation state, family and religion were blended together in an effective constellation with more left-wing views on raising the standard of living of all population groups and less unequal distribution of income and opportunities. The national welfare state was central to this constellation. Over time, and especially after 1980 with the liberalisation that was initiated at that time, the nation state lost influence and uncertainty also increased, not only about economic developments but about cultural changes too ${ }^{77}$.

National politics and politicians were no longer in a position to correct this. Growing de-politicisation and an increasingly technocratic approach to policy-making reinforced this tendency. Winkler concludes that a restoration of political trust is necessary. This means that (1) the central parties must state more clearly what they stand for, (2) democratically legitimate institutions must be formed at European level that are not just concerned with the requirements of the market but are also prepared to make political assessments, and if (2) proves impossible, (3) political parties should organise a stronger nation state. Political deliberation should then take place at that level, including with regard to globalisation. If this does not happen, then the populist parties will gain control; not only will globalisation then be hit hard, but national economies and society will suffer too.

Inglehart and Norris regard the cultural factor as more decisive ${ }^{78}$. They interpret the emergence of more populist movements as a reflection of the loss of power and status of a formerly dominant group, namely the white breadwinner. As well as contending with unemployment and more uncertainty about income, this group has also faced the collapse of beliefs that they used to regard as important. They struggle with the emancipation of women, with same-sex marriage, with the decline

\footnotetext{
76 See A. Winkler (2017), Politikfähigkeit wieder herstellen. 15 Punkte zu Populismus: Ursachen und Gegenrezepte, IFO-Schnelldienst, 70(12), 6-8.

77 See e.g. M. Kneuer (2017), Das Gespenst des Nationalpopulismus, IFO-Schnelldienst, 70(12), 13-16.

78 See Inglehart and Norris (2016), Trump, Brexit and the rise of populism: Economic have-nots and cultural backlash, Harvard Kennedy School of Government, Research working paper, RWP16-026.
} 
of faith, and with the influx of immigrants. Gidron and Hall also emphasise this cultural aspect ${ }^{79}$.

For Foster and Frieden, the economic arguments, the loss of work, uncertainty about income and inadequate education, are more decisive than the cultural factors ${ }^{80}$. The economic line of argument can also be found in the latest annual report of the EEAG. This focuses in detail on the disconcerting rise of populism in Europe and the US ${ }^{81}$. This stems from increasing uncertainty about jobs and incomes for many people, an unfair distribution of the costs of the 2008 crisis and globalisation, and a loss of democratic control over economic policy. If the populists were in charge, this could mean greater protectionism with regard to goods, services, capital and people, as well as a departure from the European Union, a farewell to the euro, and an expansionary fiscal policy at national level to give extra support to certain groups. The EEAG believes that these proposals could cause a great deal of damage. In their opinion, economists should not shy away from the debate about this dissatisfaction and the negative consequences of these proposals. It believes that the solution lies firstly in adapting the welfare state to cover the costs more effectively of those who have lost out-without spelling out exactly how this could be done-but is also in favour of delegating more tasks to independent institutions such as the $\mathrm{ECB}^{82}$.

Dennis Snower has also addressed the subject of social discontent. In his view, until 1980, economic and social developments more or less kept step with one another ${ }^{83}$. He calls this a 'convenient coupling'. He sees things as having gone wrong after 1980, when there was a 'dangerous decoupling' because of globalisation, with more inequality and loss of social ties. In addition to globalisation, he cites digitisation and then robotisation as factors that have contributed to a skill-biased technological advance at the expense of the lower-skilled.

In short, numerous explanations have recently been offered for why populism is on the rise, what has caused the increase in uncertainty, and what kind of repercussions this might have if nothing changes. Globalisation and technological development are the main determinants, operating worldwide, while the other factors mentioned-the liberalisation of markets, the relative decline of government interventions, the reduction of the welfare state, the increase of differences in educational level between people with the accompanying consequences on labour market outcome, the strong increase of immigration and the loss of social trust-all seem to widen the social differences. So far, politicians have not found the right answer to stop these processes.

\footnotetext{
79 See Gidron and Hall (2017), The politics of social status: Economic and cultural roots of the populist right, To be published in British Journal of Sociology, vol 51, special issue, November.

80 See Foster and Frieden (2017), Crisis of trust: Socio-economic determinants of Europeans' confidence in government, European Union Politics, 18(4), 511-535.

81 See European Economic Advisory Group at Cesifo, The EEAG report on the European economy (2017), Munich, special chapter 2: Economic Policy and the Rise of Populism-It's Not So Simple.

82 How this is reconciled with greater democratic engagement is not immediately clear.

83 See Snower (2017), The Dangerous Decoupling, downloaded via www.g20-insights.org.
} 


\subsection{From globalisation to social unrest}

This chapter has provided an overview of the social development of the more developed countries, under the influence of globalisation in all its facets, technological development and digitalisation. A picture has emerged of a relatively positive development in developed countries until 1980, in line with the picture outlined for the Netherlands in earlier sections, but of more and more negative developments since 1980. Economic growth has been lower than in the period up to 1980, unemployment has been higher, income inequality has risen slightly, and labour market flexibility has grown in various forms, to name a few economic aspects. Things have also gone less well in socio-cultural and social terms. The transfer of powers to international rather than national bodies and authorities has for the most part not been accompanied by an increase in the possibilities for political influence at that level. Under pressure from often mandatory economic frameworks, national fiscal policy and related expenditure on health care, education, social care and social security have been scaled back. This has reinforced the technocratisation of policy. In addition, there has been the struggle with immigration. Where people are affected, it has been less possible to support them and give them new prospects. As a result, the delicate balance between economic change and social stability seems to have been disturbed, leading to increased dissatisfaction and unrest.

Another point can be added here that receives somewhat less attention in the various studies, namely regional demographic developments in conjunction with changing educational patterns. It was previously stated that some regions have been disproportionately hit by imports because of the specific economic structure there. These tend to be the more peripheral regions, which are often also areas where fewer higher education institutions can be found. It was noted that the average educational level has constantly increased, not just in the Netherlands but in all other countries too. This implies that increasing numbers of pupils and students are attending colleges and universities. Because these institutions are present in only a limited number of locations, this means that qualified students move out of their home region to university towns elsewhere. The higher the educational level, the greater the probability these moves occur. After graduating, these young people focus strongly on labour markets where their expertise is in demand. These tend to be metropolitan areas. For the original region, this means not just that the (working) population may decrease, but that the average level of education will lag behind the national average. This will make the region less attractive for companies to invest in, given the relatively high wage costs in this part of the world. When the structure of the labour force is more one-sided, with fewer higher-skilled workers, a region becomes less attractive for potential investors. This in turn can raise unemployment. In addition, due to population shrinkage, the provision of facilities may come under pressure. Without enough consumers, there will be less shops, without young people less schools, and with less people also less public transport. All these things undermine both the attractiveness and the social stability of the region. Those who live in such regions can end up feeling that they have missed the boat, that they are being abandoned, and that no one cares about them anymore. The Netherlands is a small country, but even here these processes are visible. For 
more serious examples, one can point to the rust belts in the United States and the United Kingdom, but also to regions in Germany's new federal states. The interplay of all these vicious cycles with regard to education, globalisation, technology and demographics is contributing to this growing imbalance.

\section{Back in balance?}

The starting point for this essay was a sense of unease about social developments in recent years: stagnant growth, unemployment not dramatically high, but far more flexible jobs with uncertain incomes and prospects, social unrest, growing dissatisfaction with national politics culminating in the growth of populist parties, emerging resistance to international economic influences and international organisations such as the EU. How could these things be explained, and what lay behind them? It was noticeable that these themes were not exclusively Dutch: on the contrary, in other countries the situation was even more uncertain.

On the basis of Milanovic's graph, it was concluded that the recent global development could be described as remarkably positive. At the same time, developments for those on lower incomes in the more developed countries turned out to have been less favourable. Five relevant processes, economic growth, income distribution, demographics, education and globalisation, were then examined. The overall picture was till the 1980s quite positive, but afterwards more clouded: growth was systematically decreasing, relatively little change in income distribution, increasingly radical demographic changes, dramatic changes in educational levels, and a sharp acceleration in globalisation after 1980. In the following section, based on these changes, we considered what this implied for socio-economic development more broadly. It was noted that dynamism was the characteristic feature of almost the entire post-war period. In the last 70 years, the Dutch economy and society have changed fundamentally. It was observed that during the reconstruction phase, till the early 1970s, these changes occurred relative smoothly, were widely accepted and benefited almost everyone, while in the post-1980 phase a clearer distinction emerged between people with lower and higher levels of education. The latter's prospects have not changed dramatically. There may have been less income growth, but there have been plenty of jobs, both within the Netherlands and abroad, and prospects have been bright. For the lower-skilled, prospects have increasingly become less positive: fewer jobs, more and more flexible work, stagnating income development, dissatisfaction with the loss of facilities, and immigration being seen as a threat.

Populist views are characterised by a fear of outside influence. Some would like to build a big wall (at someone else's expense), others want to leave the EU, and still others want to take back control of the borders. How disadvantageous is globalisation, then? This is the question that was explored in the fifth section. Globalisation is in the end still positive, but it is becoming increasingly clear that there are also drawbacks to globalisation, drawbacks that are becoming ever more acute, and that these drawbacks are increasingly affecting specific groups, namely the lower-skilled. The mechanisms that have been developed so far to compensate globalisation's losers, such as a progressive tax system and a welfare state that 
helps people get back into work, functioned adequately for a long time, but are now starting to show signs of wear and tear. More and more people, especially-but not only-those with a lower level of education, are feeling the pressure from outside. Their jobs-whose increasingly flexible character already makes them less than satisfactory - are at stake, their income growth is limited, and at the same time the government feels compelled to make cuts in all kinds of facilities that they urgently need. Just when they want certainty, it melts away like snow in the sun. Just when they need more protection, the government is no longer able to provide it. Just when they want to benefit more from the modest increase in prosperity, they are forced to realise that they have fallen behind while others benefit. That this results in social discontent is not particularly surprising.

What can be done about this? How do we ensure a more inclusive future? In the preceding analysis it was shown that globalisation and technological development are crucial determinants. They exert on the whole a positive contribution to economic growth. Protectionist measures are not the right solution. Most measures to restrict these processes, from raising tariffs to closing borders, will in the end have detrimental consequences. It is probably more rewarding to strengthen the most crucial factor of production, labour, and to rethink national welfare state arrangements in such a way that it stimulates adjustment processes, but at the same time also offers also more certainties, in income and facilities, for those who are lagging behind.

The first suggestion is that both government and individuals should invest much more in education. This is the crucial variable for our future. Only with well-educated people can our current prosperity be maintained in the future, in conditions of social stability. Of course, not all people can realise a higher education, but at the lower level there is ample room for improvement. It is a serious matter when children have already dropped behind by the time they are entering primary school, and that these gaps are scarcely reduced. If we do not want this, much more needs to be done at all educational stages, from pre-school via university to life-long learning. This also applies to the commitment of pupils and students. Very probably that implies higher expenditures, but the social return will be impressive. If we want to avoid the division that is threatening to open up, education is the most important factor to deal with. Recent decades have shown a major rise in demand for education at all levels, but the expenditures (as share of GDP) has not increased. The consequence has been that at all levels the quality has come under pressure. Here a catching up policy is possible and crucial.

More expenditures on education are certainly an important factor in reducing a major inequality, but it cannot be the only one. In its aim to stabilize or, even better, to reduce the tax and premium rates, the reduction in government expenditures have had major consequences on all kind of public services, like defence, education, culture, monument conservation, health care, safety second and social security arrangements. Often there was more emphasis on real income improvements at the individual level, also by entailing the implementation of tax cuts. This strategy ignored the damage done by the reduction of expenditures on the quantity and quality of these services, and their impact on the welfare distribution. Instead of a reduction in taxes and premiums, an increase seems more rewarding in bringing about more equality in society. 
The third suggestion is related to social division. It should be strived for a minimum level of provision for certain public services. All too often, public services are scrapped because the government no longer sees any way of maintaining them in view of budget restrictions and rising costs. Sometimes the argument is also used that people must take responsibility for these things themselves. Also a shrinking population in certain regions is used as an argument to cut such services. The problem is that these reductions can reduce the accessibility of certain services, especially for the more vulnerable groups in society. People with higher incomes, often the more educated ones, have on the whole more options to compensate these reductions. People with lower income do not always have these options, with potentially detrimental consequences for these individuals but also for society. Of course, it is also important to consider how these services can be run as efficiently as possible, but financial considerations should not be the sole factor. In addition, some of these functions, when restored, could provide employment for the lower-educated.

The fourth suggestion is to take a good look at the design of international economic relations. Is it really essential to make increasingly far-reaching trade agreements, with more and more free trade, or are the increasing disadvantages in terms of social instability now beginning to outweigh the benefits? How positive is it to continue facilitating short-term cross-border financial flows? How helpful is it to allow countries to remain in (or join) a currency union when its effects are more oppressive than stimulating? A new Bretton Woods-like arrangement could be very helpful to bring about conditions for a stable and inclusive national and international development pattern.

The final, fifth suggestion is the need for a new, convincing, positive narrative, a narrative that society as a whole can identify with. What are we actually striving for together, what do we want to achieve in the coming years, what are relevant goals? The great advantage of the reconstruction period was that with everyone's efforts a better future for all was said to be possible, for both present and future generations. Over time, that vision has disappeared into thin air. Partly because of this disappearance, we are also less keenly aware of how the balance is changing between economic change and social stability, thereby jeopardising many people's prospects. This lack of a common narrative opens the door for all those politicians that have quick and easy solutions for major problems. These solutions do attract a lot of attention, especially from those at the losing side. In recent years many countries saw unexpected outcomes with regular votes of referenda. Brexit, Trump, and the rise of populist parties in many European countries are clear examples.

So far the reaction, at national level but certainly also from the EU, has been rather technocratic. Often the main argument is that such solutions are economically disadvantageous. There is nothing wrong with pragmatism and responsible technocracy, but that does not appeal to those who have the feeling that their demands are not heard anymore. Here populist parties are seizing the opportunity. Also at the EU level we are in need of a new narrative, a narrative which recognises and addresses the growing social imbalance, and is clearly aimed at achieving greater inclusiveness. We should not wait too long .... 
Open Access This article is distributed under the terms of the Creative Commons Attribution 4.0 International License (http://creativecommons.org/licenses/by/4.0/), which permits unrestricted use, distribution, and reproduction in any medium, provided you give appropriate credit to the original author(s) and the source, provide a link to the Creative Commons license, and indicate if changes were made.

\section{References}

ABN AMRO Euro Watch (2017). Why is productivity growth so low? https://insights.abnamro.nl/en/ download/109435/

Baldwin, R. (2016). The Great Convergence, information technology and the new globalization. Cambridge: Belknap Press.

Bank Group (2016). Polarization and populism. http://pubdocs.worldbank.org/en/278581479765753603/ ECA-Economic-Update-Nov-2016-Eng.pdf Europe and Central Asia economic update, November 2016.

Barclays (2017). The politics of rage. https://www.investmentbank.barclays.com/our-insights/politics-ofrage.html (Created 9 Mar 2017)

Bavel, B. van (2016). De stijging en daling van het arbeidsaandeel over de lange termijn. Economisch Statistische Berichten, 101(4743), 696-701. The rise and decline of the labor income share in the long run.

Bergeaud, A., Cette, G., \& Lecat, R. (2017). Total factor productivity in advanced countries: a longterm perspective. http://www.csls.ca/ipm/32/bergeaud_cette_lecat\%20version\%202.pdf OECD, International Productivity Monitor, 32, 6-24.

Bertelsmann Stiftung (2016). Europäer nehmen Globalisierungsängste mit in die Wahlkabine. https:// www.bertelsmann-stiftung.de/de/themen/aktuelle-meldungen/2016/november/europaeer-nehmenglobalisierungsaengste-mit-in-die-wahlkabine/ (Created 30 Nov 2016). EUPINIONS, 30-11-2016.

Bertelsmann Stiftung (2017). Wohlstand für alle. Wie inklusiv ist die soziale Marktwirtschaft? https://www.bertelsmann-stiftung.de/fileadmin/files/BSt/Publikationen/GrauePublikationen/NW_ Soziogramm.pdf

Boston Consulting Group (2016). Inclusiviteit: in ieders belang. Een prioriteit voor politiek en bedrijfsleven. Amsterdam: Boston Consulting Group. Inclusiveness: Important for all. Priority for politics and business

Bovens M., \& Wille A. (2017). Diploma democracy. The rise of political meritocracy. Oxford: Oxford University Press.

Brakel, M. van den, \& Otten, F. (2017). Door crisis en vergrijzing stijgt ongelijkheid in primair inkomen. Economisch Statistische Berichten, 102(4756), 579-582. Because of crisis and greying inequality in primary incomes is increasing.

Citi GPS, \& Oxford Martin School (2017). Inequality and prosperity in the industrialized world. Addressing a growing challenge. https://www.oxfordmartin.ox.ac.uk/downloads/Citi_GPS_Inequality.pdf

Council for Economic Affairs (2007). Van de verdeling komt de welvaart. Distribution is determining welfare

CPB Netherlands Bureau for Economic Policy Analysis (2017). Macro economic forecast 2017. https://www.cpb.nl/sites/default/files/omnidownload/CPB-Macro-Economic-Outlook-MEV-2017translation-chapter1.pdf Macro Economische Verkenning 2017.

CPB Netherlands Bureau for Economic Policy Analysis, Statistics Netherlands, \& De Nederlandse Bank (2017). Herziening methode arbeidsinkomensquote. The Hague, https://www.cpb.nl/publicatie/ herziening-methode-arbeidsinkomensquote

European Economic Advisory Group at Cesifo (2017). The EEAG report on the European economy 2017. https://www.cesifo-group.de/DocDL/EEAG-2017.pdf Munich, special chapter 2.

Foster, C., \& Frieden, J. (2017). Crisis of trust: Socio-economic determinants of Europeans' confidence in government. European Union Politics, 18(4), 511-535.

Fratzscher, M. (2016a). Hohe Ungleichheit durch schlecht funktionierende soziale Marktwirtschaft. Wirtschaftsdienst, 96(6), 583-588.

Fratzscher, M. (2016b). Verteilungskampf - Warum Deutschland immer ungleicher wird. Munich: Carl Hanser.

Gidron, N., \& Hall, P. A. (2017). The politics of social status: Economic and cultural roots of the populist right. British Journal of Sociology, 68(SI), 57-S84.

Hellwig, M. (2017). Deutschland und die Finanzkrise(n). Wirtschaftsdienst, 97(9), 606-607. 
Inglehart, R. F., \& Norris, P. (2016). Trump, Brexit and the rise of populism: Economic have-nots and cultural backlash. https://research.hks.harvard.edu/publications/getFile.aspx?Id=1401 Harvard Kennedy School of Government, Research working paper, RWP16-026.

International Monetary Fund (2017a). Understanding the downward trend in labor income shares. http:// www.sipotra.it/wp-content/uploads/2017/04/Cap3.pdf IMF, World Economic Outlook 2017, Chapter 3.

International Monetary Fund (2017b). Staff report 2017 for the article IV consultation The Netherlands. Washington: International Monetary Fund.

Kneuer, M. (2017). Das Gespenst des Nationalpopulismus. IFO-Schnelldienst, 70(12), 13-16.

Krugman, P. (2016). Leave zombies be. Finance and Development, 53(4), 11.

Mallaby, S. (2016). Globalization resets. Finance and Development, 53(4), 6-10.

Milanovic, B. (2016). Global inequality. A new approach for the age of globalization. Boston: Harvard University Press.

Ministry of Finance (2017). Government Budget 2018. The Hague

Mustert, G. R. (1976). Van dubbeltjes en kwartjes. The Hague, https://www.wrr.nl/publicaties/publicaties/ 1976/05/24/van-dubbeltjes-en-kwartjes.-een-literatuurstudie-over-de-ongelijkheid-in-de-nederlandseinkomensverdeling

Obstfeld, M. (2016). Get on track with trade. Finance and Development, 53(4), 12-16.

Organisation for Economic Cooperation and Development (2012). Labour losing to capital: What explains the declining labor share? http://www.oecd.org/els/emp/EMO\%202012\%20Eng_Chapter\%203.pdf OECD, Employment Outlook 2012, Chapter 3.

Organisation for Economic Cooperation and Development (2016). Economic survey The Netherlands 2016. Paris: OECD.

Organisation for Economic Cooperation and Development (2017). How technology and globalisation are transforming the labour market. In Employment outlook 2017. Paris: Organisation for Economic Cooperation and Development. chapter 3.

Ostry, J. D., Lougani, P., \& Furceri, D. (2016). Neoliberalism oversold? https://www.imf.org/external/pubs/ $\mathrm{ft} /$ fandd/2016/06/pdf/ostry.pdf IMF Finance \& Development, June 2016, 38-41.

Pen, J., \& Tinbergen, J. (1977). Naar een rechtvaardiger inkomensverdeling. Amsterdam: Elsevier. Towards a more just income distribution

Philippon, T. (2017). Brexit and the end of the great policy moderation. https://www.brookings.edu/wpcontent/uploads/2017/02/philippontextfall16bpea.pdf Brookings Papers on Economic Activity, Fall 2016, 385-393.

Piketty, T. (2014). Capital in the 21 century. Cambridge: Harvard University Press.

Polyakova, A., \& Fligstein, N. (2016). Is European integration causing Europe to become more nationalist? Evidence from the 2007-2009 financial crisis. Journal of European Public Policy, 23(1), 60-83.

Reinhardt, C. M., \& Rogoff, K. S. (2011). This time is different, eight centuries of financial folly. Princeton: Princeton University Press.

Rodrik, D. (2017). Populism and the economics of globalization. https://drodrik.scholar.harvard.edu/ files/dani-rodrik/files/populism_and_the_economics_of_globalization.pdf NBER Discussion paper 12119.

Schuyt, C.J. M., \& Taverne, E. R. M. (2000). 1950, Welvaart in zwart-wit: de Nederlandse wederopbouw in 12 beelden. The Hague: Sdu. Growth in black and white: The Netherlands post-war reconstruction in 12 images

Scientific Council for Government Policy WRR (1980). Plaats en toekomst van de Nederlandse industrie. https://www.wrr.nl/binaries/wrr/documenten/rapporten/1980/05/21/plaats-en-toekomst-van-denederlandse-industrie/plaats-toekomst-nederlandse-industrie.pdf Industry in the Netherlands: its place and future.

Scientific Council for Government Policy WRR (1996). Social dichotomy in perspective. https://english. wrr.nl/binaries/wrr-eng/documents/reports/1996/12/18/social-dichotomy-in-perspective/SummarySocial-dichotomy-perspective.pdf Report to the Government nr. 50.

Scientific Council for Government Policy WRR (1998). The state in motion. The Hague: Scientific Council for Government Policy WRR. Preliminary Study 100

Scientific Council for Government Policy WRR (2018). The fall of the middle class? Stability and vulnerability in the middle segment of society. https://english.wrr.nl/binaries/wrr-eng/documents/ investigation/2018/02/14/the-fall-of-the-middle-class/V37+The+fall+of+the+middle+class_web. pdf WRR Verkenningen, The Hague.

Snower, D. (2017). The dangerous Decoupling. www.g20-insights.org 
Statistics Netherlands (2016). Kernprognose 2016-2060: 18 miljoen inwoners in 2040 voorzien. The Hague: Statistics Netherlands. Main demographic prognosis 2016-2060, 18 million inhabitants forecasted for 2040

Statistics Netherlands (2017). Helft niet-werkenden met uitkering kan/wil niet werken. Vol. 2017 (pp. 7-10). The Hague: Statistics Netherlands. Half of the non-working population on benefit can't work or does not want to work, press release 7-10-2017

Südekum, J. (2017). Die Globalisierungsverlierer kompensieren - aber wie? Wirtschaftsdienst, 97(8), 566-570.

United Nations Conference on Trade and Development (2016). World investment report 2016. http:// unctad.org/en/PublicationsLibrary/wir2016_en.pdf

United Nations Development Programme (2016). Human development report 2016. Human development for everyone. http://hdr.undp.org/sites/default/files/2016_human_development_report.pdf

Wagner Commission (1981). Een nieuw industrieel elan. The Hague: Wagner Commission. A new industrial elan

Winkler, A. (2017). Politikfähigkeit wieder herstellen. 15 Punkte zu Populismus: Ursachen und Gegenrezepte. IFO-Schnelldienst, 70(12), 6-8. 